\title{
Tapping the Reservoir: Mutual Fund Litigation Under Section 36(a) of the Investment Company Act of 1940
}

William K. Sjostrom, Jr. ${ }^{*}$

\section{INTRODUCTION}

In September 2003, the staid mutual fund industry was rocked by an announcement from New York Attorney General Eliot Spitzer that his office had settled for $\$ 40$ million charges of improper trading in mutual fund shares by hedge-fund Canary Investment Management LLC, and related entities. ${ }^{1}$ According to Spitzer, various mutual funds had allowed Canary to engage in late trading and market timing with respect to fund shares. ${ }^{2}$ Mutual fund shares are priced once a day at 4 PM (EST). Orders to buy or sell fund shares placed at or before 4 PM on a particular day are executed at that day's price, and orders placed after 4 PM on a particular day are supposed to be executed at the next day's price. Late trading involves placing orders after 4 PM but receiving the price determined as of 4 PM that day. ${ }^{3}$ With late trading, traders are attempting to capitalize on market moving information released publicly after 4 PM. $^{4}$ As Spitzer's complaint against Canary put it, "[1]ate trading can be analogized to betting today on yesterday's horse races."

\footnotetext{
Associate Professor, Salmon P. Chase College of Law, Northern Kentucky University. I would like to thank Professor Antony Page for his comments on this Article

1. Randall Smith \& Tom Lauricella, Spitzer Alleges Mutual Funds Allowed Fraudulent Trading, WALL St. J., Sept. 4, 2003, at A1.

2. Id.

3. SEC v. JB Oxford Holdings, Inc., Litigation Release No. 18850, 83 S.E.C. Docket 1988 (Aug. 25, 2004), available at 2004 WL 1908193, at $* 2$; Complaint at 3, State v. Canary Capital Partners, LLC, No. 402830/2003 (N.Y. Sup. Ct. filed Sept. 3, 2003), available at http://www.oag.state.ny.us/press/2003/sep/canary_complaint.pdf [hereinafter Spitzer Complaint].

4. For example, if an industry-leading technology company announced unexpectedly strong earnings after 4 PM, it is likely that shares in technology companies and hence shares in mutual funds with large investments in technology companies would be up the next day. Therefore, late traders enter buy orders for shares of technology-focused mutual funds after the announcement but get the pre-announcement price on the shares. Karen Damato, 'Timing' at Mutual Funds Can Cost $2 \%$ a Year, WALL ST. J., Sept. 19, 2003, at C1.

5. Spitzer Complaint, supra note 3, at 3.
} 
Market timing involves the frequent trading of mutual fund shares in an effort to take advantage of inefficiencies in mutual fund share pricing. ${ }^{6} \quad$ A popular market-timing strategy entails trading in international stock mutual funds. For many international funds, prices set at 4 PM are partially based on closing prices of Asian stocks, which were determined more than ten hours earlier. If the U.S. market has risen sharply, it is a good bet that Asian markets will rise the next day. Knowing this, a trader buys shares in an international fund right before the 4 PM cutoff in the United States and sells the shares at a profit the next day, assuming the expected rise in Asian stocks materializes. ${ }^{7}$

Late trading is illegal. ${ }^{8}$ Market timing is not in and of itself illegal, ${ }^{9}$ but most mutual fund companies discourage it and have public written policies to that effect. ${ }^{10}$ Both late trading and market timing hurt longterm fund investors because the late traders and market timers are "siphoning off some of the profit that would otherwise have gone to those funds' long-term investors." 11 Some portfolio managers, nonetheless, have allowed select firms like Canary to engage in such

6. JB Oxford Holdings, $2004 \mathrm{WL} 1908193$, at *2 (quoting SEC complaint).

7. Damato, supra note 4.

8. SEC v. Mutuals.com, Inc., Litigation Release No. 18489, 81 S.E.C. Docket 2402 (Dec. 4, 2003), available at 2003 WL 22873178 , at $* 5$.

9. Disclosure Regarding Market Timing and Selective Disclosure of Portfolio Holdings, Release Nos. 33-8343 \& IC-26287, 81 S.E.C. Docket 2425 (Dec. 11, 2003), available at 2003 WL 22926837 , at *13 [hereinafter Market Timing Disclosure Release].

10. Spitzer Complaint, supra note 3, at 2; Tom Lauricella, Two-Tier System: For Staid MutualFund Industry, Growing Probe Signals Shake-up, WALL St. J., Oct. 20, 2003, at A1.

11. Damato, supra note 4.

[M]arket timing may dilute the value of long-term shareholders' interests in a mutual fund if the fund calculates NAV using closing prices that are no longer accurate. Dilution may occur, for example, if fund shares are overpriced because redeeming shareholders will receive a windfall at the expense of the shareholders that remain in the fund. Similarly, dilution may occur when a fund sells its shares at a price lower than its NAV.

Market Timing Disclosure Release, supra note 9, at*4.

To understand how the returns of a long-term fund investor can be diluted by shortterm trading, consider a simple hypothetical example: a stock fund with just 24 investors holding stocks valued at $\$ 2,400$, or $\$ 100$ for each investor. A short-term trader who has special insight that the share price will rise tomorrow then invests $\$ 100$ for the 25 th fund share.

The fund's portfolio manager, receiving notice of that cash inflow after the market is closed, can't put that additional cash to work immediately. So the fund heads into the next trading day with the same stock holdings as before and an added $\$ 100$ in cash. It's a good day as expected, and the fund's stocks rise $20 \%$. But because of the cash cushion, the fund's overall portfolio gains only $19.2 \%$, not the full $20 \%$.

Damato, supra note 4. 
trading in exchange for indirect payments from the traders to the portfolio managers. $^{12}$

The Canary settlement was so shocking because Spitzer's complaint against Canary cited four large fund companies, Bank of America Corp., Bank One Corp., Janus Capital Corp., and Strong Capital Management Inc., each of which manages billions of dollars of investors' funds. ${ }^{13}$ Further, Spitzer noted that "future charges were 'almost certain' to be brought against mutual-fund companies themselves and possibly others." 14 Spitzer was of course correct: new revelations of improprieties at mutual funds became seemingly a daily occurrence thereafter, and one big fund company after another was pulled into what was soon labeled the "mutual fund scandal.","

Not surprisingly, the mutual fund scandal has precipitated congressional hearings, new regulations, and a flood of SEC enforcement actions and private lawsuits against mutual fund companies and their board members, officers, and investment advisers. ${ }^{16}$ Many of these actions and lawsuits allege, among other things, violations of section 36(a) of the Investment Company Act of 1940 (ICA). ${ }^{17}$ Section 36(a)

12. See Tom Lauricella, Scandal Reaches Far and High, Wall ST. J., Jan. 8, 2005, at R1 ("In return for allowing this trading, many of these executives asked for or accepted payments in the form of added investments on which the fund companies would earn greater fees - a particularly welcome source of revenue during the bear market when other fee-generating assets were often declining."). As described in the Spitzer Complaint:

Typically, Canary would agree with the fund manager on target funds to be timed . . . and then move the timing money quickly between those funds and a resting place in a money market or similar fund in the same fund family. By keeping the money-often many million dollars - in the family, Canary assured the manager that he or she would collect management and other fees on the amount [since these fees are typically based on the percentage of assets under management] whether it was the target fund, the resting fund, or moving in between. ...

... As an additional inducement for allowing the timing, fund managers often received "stick assets." These were typically long-term investments made not in the mutual fund in which the timing activity was permitted, but in one of the fund manager's financial vehicles (e.g., a bond fund or a hedge fund run by the manager) that assured a steady flow of fees to the manager.

Spitzer Complaint, supra note 3, at 12.

13. Id. at $18-41$.

14. Smith \& Lauricella, supra note 1 .

15. See Investment Company Governance, Investment Company Act Release No. IC-26520, 83 S.E.C. Docket 1384 (July 27, 2004), available at $2004 \mathrm{WL} 1672374$, at $* 2$ [hereinafter Investment Company Governance Release] (stating that amendments were proposed "in the wake of a troubling series of enforcement actions" involving mutual fund abuse).

16. See James N. Benedict \& Mary K. Dulka, Recent Developments in Litigation Under the Investment Company Act of 1940, in THE INVESTMENT MANAGEMENT INSTITUTE, 2004: A SEMINAR FOR '40 ACT LAWYERS 1149, 1224 (Barry P. Barbash \& Paul F. Roye eds., 2004) (stating that there has been a "raft of private civil lawsuits" based on improper trading allegations).

17. Id. at 1227 . 
provides a federal cause of action for "a breach of fiduciary duty involving personal misconduct in respect of any registered investment company" by an officer, director, investment adviser, or principal underwriter of an investment company, among others. ${ }^{18}$ The ICA, however, provides no guidance as to the content of this fiduciary duty or as to the meaning of the phrase "involving personal misconduct." Nor is there much relevant legislative history, case law, or scholarly commentary on these issues.

This Article seeks to fill the gap. Part II outlines the typical operating structure of a mutual fund and describes the roles of the fund's board of directors and investment adviser. Part III provides background on the ICA and its application to a mutual fund. Part IV explores in depth the "breach of fiduciary duty" standard under ICA section 36(a). After examining relevant state law on fiduciary duties, it concludes that given the unique structure of a mutual fund, federal courts should tailor the standard specifically for the investment company industry, drawing on state law when appropriate. Part V addresses in detail the "involving personal misconduct" standard under section 36(a). It concludes that, in light of relevant legislative history, federal courts should interpret the standard to reflect the substance of the business-judgment rule. Lastly, Part VI states a brief conclusion.

\section{MutuAl Fund STRUCTURE}

A mutual fund pools the money of investors to collectively invest in stocks, bonds, and other securities. ${ }^{19}$ Investors receive shares in the fund in exchange for their money. ${ }^{20}$ This allows mutual fund investors to get the benefit of professional investment management and diversification, because the fund's assets are typically invested in diversified portfolios selected by professional money managers. ${ }^{21}$ Mutual funds provide "an economical, convenient way for the average investor to benefit from professional money management much like large institutions and

18. 15 U.S.C. \$ 80a-35(a) (2000). Because section 29 of ICA amended the Bankruptcy Act of 1898, it was not codified in Title 15. See Pub. L. No. 768, § 29, 54 Stat. 835 (1940) ("Section 67 of [the Bankruptcy Act of 1898] is amended by adding at the end thereof the following . . .."). Accordingly, section 30 of the ICA is codified at 15 U.S.C. $\S 80 a-29$, section 31 at 15 U.S.C. $\S 80$ a30 , and so on.

19. InV. Co. Inst., 2004 Mutual Fund FACt BoOK 1 (44th ed. 2004), available at http://www.ici.org/pdf/2004_factbook.pdf [hereinafter MUTUAL FUND FACT BOOK].

20. Id.

21. Id. at 1,9 . 
wealthy investors receive." 22 Many average investors have in fact invested in mutual funds. "An estimated 91 million individuals and 53.3 million U.S. households owned mutual funds in 2003."23 As of December 31, 2003, mutual funds had assets under management of approximately $\$ 7.4$ trillion. ${ }^{24}$

Each mutual fund is a separate legal entity-typically either a corporation or a business trust. ${ }^{25}$ Unlike a typical corporation, however, a mutual fund is normally externally managed. ${ }^{26}$ "A mutual fund is a 'mere shell,' a pool of assets consisting mostly of portfolio securities that belongs to the individual investors holding shares in the fund." ${ }^{27}$ Instead of having its own employees, a mutual fund retains third-party service providers to manage the fund's investment portfolio, market and sell the fund shares to investors, execute shareholder transactions, maintain shareholder records, etc. ${ }^{28}$ Broad oversight of these various service providers is provided by the fund's board of directors, which is elected by its shareholders. ${ }^{29}$

A fund typically is organized and launched by its investment adviser. ${ }^{30}$ The investment adviser handles portfolio management and most other day-to-day operations of the fund. ${ }^{31}$ A fund's investment adviser provides these services to the fund pursuant to a written advisory agreement, which under the ICA has to be approved by a majority of the fund's directors and shareholders. ${ }^{32}$ Typically, the advisory agreement specifies that the investment adviser will manage the fund's investments and administer its operations subject to the oversight of the fund's board

22. Id. at 9 .

23. Id. at 79 .

24. Id. at 1 .

25. ROBERT A. Robertson, Fund GOVERnANCE: LEgAL Duties OF INVESTMENT COMPANY DiRECTORS $§ 2.02$ (2001); Philip H. Newman, Legal Considerations in Forming a Mutual Fund, SJ095 ALI-ABA 22, 22 (2003).

26. Mutual Fund FaCt BooK, supra note 19, at 2; Task Force on Fund Dir's Guidebook (2002-2003), Am. Bar Ass'n, Fund Director's Guidebook, 59 Bus. LAW. 201, 207 (2003).

27. Tannenbaum v. Zeller, 552 F.2d 402, 405 (2d Cir. 1977), cited in Burks v. Lasker, 441 U.S. 471, 480-81 (1979). See also Zell v. InterCapital Income Sec., Inc., 675 F.2d 1041, 1046 (9th Cir. 1982) ("The fund is a shell.").

28. Mutual Fund FACT BOOK, supra note 19, at 7-8.

29. Id. at 8. Technically, if a mutual fund is organized as a business trust, it has a board of trustees instead of a board of directors and hence trustees instead of directors. ROBERTSON, supra note 25, at viii n.7. References in this Article to a board of directors and directors include a board of trustees and trustees.

30. Tannenbaum, 552 F.2d at 405; MutUAL Fund FACT BooK, supra note 19, at 8 . See also ROBERTSON, supra note $25, \S 6.01$, n.3.

31. ROBERTSON, supra note 25, § 6.01; Donald W. Glazer, A Study of Mutual Fund Complexes, 119 U. PA. L. REV. 205, 209 (1970).

32. 15 U.S.C. $\S 80 \mathrm{a}-15(\mathrm{a}),(\mathrm{c})(2000)$. 
of directors. ${ }^{33}$ Managing investments entails selecting securities based on the adviser's market research and the fund's specified investment objectives and risk tolerance. ${ }^{34}$ The adviser also provides the fund with office space and staff and maintains certain books and records for the fund. ${ }^{35}$

The fund pays the investment adviser a fee for providing these services usually equal to a percentage of the fund's net assets. ${ }^{36}$ This percentage may range from $0.05 \%$ to $1.50 \%$ of net assets. ${ }^{37}$ For many larger funds, the fee arrangement includes so-called "breakpoints." "38 Under a breakpoint structure, the fee percentage decreases at specified fund-asset levels. ${ }^{39}$ For example, the advisory agreement may provide that the adviser is entitled to a fee of $1.00 \%$ on fund net assets up to $\$ 500$ million, $0.875 \%$ on fund assets more than $\$ 500$ million and up to $\$ 1$ billion, and $0.75 \%$ on fund assets more than $\$ 1$ billion. This reflects anticipated economies of scale to be realized by the investment adviser. ${ }^{40}$ Basically, the cost to the adviser, as a percentage of fund assets, to run a \$2-billion fund should be much smaller than the cost to run a \$200million fund. ${ }^{41}$ Breakpoints allow the fund to benefit from these economies of scale. ${ }^{42}$

A mutual fund is legally required to redeem an investor's shares upon the request of the investor at a per-share price based on the thencurrent value of the fund's net assets. ${ }^{43}$ In part because of this redemption obligation, mutual funds generally continuously offer and sell shares to the public in an effort to maintain or increase assets under management, notwithstanding redemptions from existing investors. ${ }^{44}$ Thus, attracting new investors can be critical to the continued growth and success of a fund. ${ }^{45}$ This job is handled by the fund's distributor, which

33. ROBERTSON, supra note $25, \S 6.02[1]$.

34. MUtUAL Fund FACT BOOK, supra note 19, at 9

35. Tannenbaum, 552 F.2d at 405; ROBERTSON, supra note 25, § 6.02[1].

36. Tannenbaum, $552 \mathrm{~F} .2 \mathrm{~d}$ at 405 .

37. ROBERTSON, supra note $25, \S 6.02[2]$.

38. Id.

39. Id.

40. Id.

41. Id.

42. $I d$.

43. MutUAL Fund FACT BOOK, supra note 19, at 12. See also ROBERTSON, supra note $25, \S$ 7.01 , at $7-2$.

44. See id.; see also TAmar Frankel \& Ann TAylor Schwing, The Regulation of Money MANAGERS $\S 5.08[\mathrm{C}][1]$, at 5-200 (2d ed. Supp. 2005) (describing how, because shares are redeemable, "assets will shrink without constant distribution of new securities").

45. See ROBERTSON, supra note $25, \S 7.01$, at 7-2. 
is typically a separate legal entity wholly owned, either directly or indirectly, by the fund's investment adviser. ${ }^{46}$ A fund's distributor provides services pursuant to a written distribution agreement, which must be approved by the fund's board of directors. ${ }^{47}$

A fund's distributor may market shares directly to the public or indirectly through other financial intermediaries such as brokerage firms, banks, retirement plans, financial planners, and life insurance companies. $^{48}$ These financial intermediaries are typically paid a commission for selling the fund shares. ${ }^{49}$ This commission may be derived from a sales charge paid by the purchaser of fund shares, from fees charged the fund for distribution, or from the adviser's profits. ${ }^{50}$ To provide investors with a choice of fee structure, a mutual fund may offer multiple classes of shares, each of which has a different fee structure. ${ }^{51}$ For example, a fund may offer class A shares where investors pay an upfront sales charge (a front-end load), class B shares where investors pay a fee when cashing out (a back-end load), and class $C$ shares where investors pay no load. ${ }^{52}$ Sellers of class A shares are compensated from the front-end load and a small annual charge paid by the fund. Sellers of class B shares are compensated by a higher annual charge paid by the fund and the back-end load when the shares are sold. Sellers of class $C$ shares are compensated by an even higher annual charge paid by the fund. ${ }^{53}$ The use of fund assets to market and sell fund shares must be done in accordance with a distribution plan approved by the fund's board of directors. ${ }^{54}$

46. See id. at 7-3; see also Tannenbaum v. Zeller, 552 F.2d 402, 405 (2d Cir. 1977) ("The sale of fund shares to new investors is generally the responsibility of a 'principal underwriter' who is usually the adviser itself or a close affiliate.").

47. 15 U.S.C. $\$ 80 a-15$ (c) (2000).

48. See ROBERTSON, supra note $25, \S 7.01$, at 7-3; see also MUTUAL Fund FACt BooK, supra note 19 , at 11 (stating that a fund sponsor, historically, would market shares directly to the public, or indirectly, relying on "brokers, financial planners, life insurance companies, and banks," and more recently, through a variety of other financial intermediaries).

49. See ROBERTSON, supra note $25, \S 7.01$ at $7-4$.

50. See id.

51. See id.

52. Ellen E. Schultz, Bewildering Class Structure is Lurking in the Shadows of Mutual Fund Investing, WALL ST. J., Feb. 21, 1996, at C1.

53. Karen Damato, What to Ask Before Investing, WALL ST. J., Oct. 4, 2004, at R1.

54. 17 C.F.R. $\S 270.12 b-1(b)(2)(2005)$. These plans are referred to as $12 \mathrm{~b}-1$ distribution plans in reference to Rule $12 \mathrm{~b}-1$ of the Investment Company Act, which specifies the requirements for such plans. See id. $\S 270.12$ b-1. Approximately fifty-nine percent of mutual funds have adopted $12 \mathrm{~b}-1$ distribution plans. ROBERTSON, supra note $25, \S 7.04$, at 7-11. Some funds do not use fund assets to market and sell shares. Instead expenses relating thereto may be covered by the investment adviser and front-end or back-end loads. Id. § 7.04, at 7-10, n.1. 


\section{INVESTMENT COMPANY ACT BACKGROUND}

The first United States mutual fund, the Massachusetts Investors Trust, was established in Boston, Massachusetts, in $1924 .{ }^{55}$ The fund quickly became a success - by the end of 1926 it had \$3.3 million (\$35.9 million adjusted for inflation) in assets under management. ${ }^{56}$ In the wake of this success, numerous other funds were launched. ${ }^{57}$ However, following the stock market crash of 1929 and Great Depression in the early 1930s, it became apparent that "there were evils, abuses and deficiencies in the organization and operation of [the mutual fund] industry which needed to be ferreted out and dealt with in some manner which would restore public confidence in the industry." 58 Hence, in 1935, Congress directed the SEC to study the mutual fund industry and report back with recommendations. ${ }^{59}$ By 1939 , the SEC had submitted to Congress the final part of an exhaustive report entitled Report of the Securities and Exchange Commission on Investment Trusts and Investment Companies ${ }^{60}$ including a proposed bill providing for the federal registration and regulation of mutual funds, among other things. ${ }^{61}$ Following extensive congressional hearings where mutual fund industry representatives vigorously opposed various sections of the bill, the SEC

55. MUtUAL Fund FACT BoOK, supra note 19, at 5; John C. Bogle, Re-Mutualizing the Mutual Fund Industry - The Alpha and the Omega, 45 B.C. L. REV. 391, 391 (2004).

56. Bogle, supra note 55, at 393.

57. Walter P. North, A Brief History of Federal Investment Company Legislation, 44 NOTRE DAME L. REV. 677, 678 (1969).

58. Id. These abuses included the following:

the promiscuous creation of investment companies where no economic need for them existed; the frequent lack of ability and experience on the part of sponsors or promoters of companies the chief appeal of which lay in the promise of expert security analysis and investment management; conflicts of interest in the sponsors, especially predominant groups of investment bankers, brokers, security dealers, and other professional financing groups; self-dealing; failure to make adequate disclosure to investors; complete and arbitrary control over the financial capital structure; failure by the sponsors to make capital contributions commensurate with the position and interests they obtained in the enterprise; failure by the sponsors to assume and live up to their fiduciary duties; and excessive compensation.

Note, Regulation of Investment Companies, 88 U. PA. L. REV. 584, 588-89 (1940) (footnotes omitted). See also Burks v. Lasker, 441 U.S. 471, 480 (1979) ("Congress was concerned about the potential for abuse inherent in the structure of investment companies."); ROBERTSON, supra note 25, $\S 1.02[1]$, at 1-42 to -44 (discussing legislative intent).

59. Burks, 441 U.S. at 480. See also 1 FrANKEL \& SCHWING, supra note 44, § 1.02[B], at 1-51 (citing congressional charge to conduct the study); 1 LOUIS LOSS \& JOEL SELIGMAN, SECURITIES REGULATION § 1-H-6, at 247 (3d ed. 1999), available in LEXIS Securities, Treatises \& Analytical materials (citing the SEC study).

60. North, supra note 57, at 678. The report was printed as H.R. Doc. No. 707 (1938).

61. 1 FRANKEL \& SCHWING, supra note 44, § 1.02[B], at 1-52. 
worked with the industry to draft a substitute bill acceptable to both parties. $^{62}$ Congress enacted this bill, with slight modifications, on August 22, 1940, as the Investment Company Act of $1940 .^{63}$ The Act "expanded the disclosure provisions already applicable to [an investment company] under the Securities Act of 1933 and Securities Exchange Act of 1934, and imposed specific requirements as to the structure and operations of mutual funds." 64

Section 7(a) of the ICA requires that investment companies register with the SEC. ${ }^{65}$ The definition of investment company includes any company that "is or holds itself out as being engaged primarily, or proposes to engage primarily, in the business of investing, reinvesting, or trading in securities." definition because it solicits investors to pool their money to invest in securities. ${ }^{67}$ The ICA classifies an investment company as either a faceamount certificate company, ${ }^{68}$ a unit investment trust, ${ }^{69}$ or a management company. ${ }^{70}$ The ICA then subclassifies a management company as either an open-end investment company or a closed-end investment company. ${ }^{71}$ These distinctions are relevant because certain provisions of the ICA apply only to certain classes or subclasses of investment companies. ${ }^{72} \mathrm{~A}$

62. ROBERTSON, supra note $25, \S 1.02[3]$, at 1-55.

63. Pub. L. No. 768,54 Stat. 789 (1940). See also RoberTSON, supra note 25, § 1.02[3], at 155 (citing 54 Stat. 789).

64. Tannenbaum v. Zeller, 552 F.2d 402, 406 (2d Cir. 1977) (citations omitted).

65. 15 U.S.C. $\S 80 a-7$ (a) (2000). See generally 1 FrANKEL \& SCHWING, supra note 44, § 24.01, at 24-5 (stating that investment companies are required to register).

66. 15 U.S.C. $\S 80 a-3(a)(1)(A)(2000)$. A face-amount security company is an investment company that issues debt securities investors purchase in installments. 15 U.S.C. $\$ 80 \mathrm{a}-2$ (a)(15) (2000). Face-amount certificate companies are almost extinct. See 1 Frankel \& Schwing, supra note $44, \S 5.08[\mathrm{~A}]$, at 5-186.

67. See supra text accompanying note 19 .

68. 15 U.S.C. $\$ 80 a-4(1)(2000)$.

69. $\S 80 \mathrm{a}-4(2)$. A unit investment trust (UIT) buys and holds a generally fixed portfolio of securities such as stocks and bonds. MUTUAL FUND FACT BOOK, supra note 19, at 12. An investor in a UIT purchases units in the trust and is entitled to a proportionate share of dividends and interest paid on investments in the trust portfolio. Id.

70. $\S 80 \mathrm{a}-4(3)$.

71. 15 U.S.C. $\S 80 \mathrm{a}-5$ (a) (2000). The ICA defines a closed-end investment company as "any management company other than an open-end company." $\S 80 \mathrm{a}-5(\mathrm{a})(2)$. The ICA defines an openend investment company as "a management company which is offering for sale or has outstanding any redeemable security of which it is the issuer." $\$ 80 a-5(a)(1)$. Hence, a closed-end investment company is a management company that does not issue redeemable shares. 1 FRANKEL \& SCHWING, supra note $44, \S 5.08[\mathrm{C}][1]$, at 5-200. Thus, the number of shares a closed-end investment company has outstanding is typically fixed. MUTUAL FUND FACT BOOK, supra note 19, at 12. If an investor wishes to cash out of a closed-end investment company it has to sell its shares to a third party because the fund is under no obligation to redeem shares. Id. Consequently, shares of closed-end investment companies trade on stock exchanges and in the over-the-counter market. Id.

72. Loss \& SELIGMAN, supra note 59, § 1-H-6a, at 242-43. 
mutual fund is technically an open-end investment company because it issues redeemable shares to investors. ${ }^{73}$ This means that an investor can cash out of a mutual fund by simply requesting that the fund redeem the investor's shares. ${ }^{74}$ The fund is required to do so at a per-share price based on the then-current value of the fund's net assets. ${ }^{75}$

Once registered, an investment company is subject to the various regulatory provisions of the ICA. ${ }^{76}$ These provisions are designed to address five primary areas: sales practices, investment advisory fees, fund management, fund capital structures, and financial statements and accounting. ${ }^{77}$ For example, section 22 (b) of the ICA addresses excessive sales loads $;^{78}$ section $36(\mathrm{~b})$ provides that the investment adviser of an investment company owes the investment company "a fiduciary duty with respect to the receipt of compensation for services, or of payments of a material nature, paid by such registered investment company;",79 section 13 prohibits an investment company from changing its stated investment policies unless authorized by a majority vote of its shareholders; ${ }^{80}$ section 18 generally prohibits an open-end company from issuing any senior securities, ${ }^{81}$ and section 30 requires investment companies to furnish semi-annual financial statements to shareholders and empowers the SEC to promulgate uniform accounting rules for investment companies. ${ }^{82}$

Under the ICA, at least forty percent of the directors on a fund's board must not be "interested persons" of the fund. ${ }^{83}$ In general terms, "interested persons" include fund insiders, members of their immediate families, insiders of the fund's investment adviser, and insiders of the

73. The statutory scheme is as follows: The Investment Company Act defines a management company as "any investment company other than a face-amount certificate company or a unit investment trust." 15 U.S.C. $\S 80 \mathrm{a}-4(3)$. An open-end investment company is "a management company which is offering for sale or has outstanding any redeemable security of which it is the issuer." $§ 80 a-5(a)(1)$. A redeemable security is "any security, other than short-term paper, under the terms of which the holder, upon its presentation to the issuer or to a person designated by the issuer, is entitled (whether absolutely or only out of surplus) to receive approximately his proportionate share of the issuer's current net assets, or the cash equivalent thereof." 15 U.S.C. $\S$ 80a-2(a)(32) (2000).

74. See MUtUAL FUnD FACT BooK, supra note 19, at 12 (discussing liquidity of mutual fund shares).

75. Id.

76. 1 FRANKEL \& SCHWING, supra note $44, \S 24.01$ at 24-5.

77. See generally Loss \& SELIGMAN, supra note 59, at § 1-H-6.

78. 15 U.S.C. $\$ 80 \mathrm{a}-22$ (b) (2000).

79. 15 U.S.C. $\$ 80 \mathrm{a}-35(\mathrm{~b})(2000)$.

80. 15 U.S.C. $\S 80 a-13(a)(3)(2000)$.

81. 15 U.S.C. $\$ 80 \mathrm{a}-18(\mathrm{f})(2000)$

82. 15 U.S.C. $\$ 80 \mathrm{a}-30(2000)$.

83. 15 U.S.C. $\S 80 a-10$ (a) (2000). 
fund's principal underwriter. ${ }^{84}$ Directors who are not interested persons of a fund are generally referred to as independent directors. ${ }^{85}$ Currently, if a fund relies on certain exemptive rules under the ICA (which is the case for most funds), at least a majority of the fund's directors must be independent. ${ }^{86}$ As a result of rules recently adopted by the SEC, this majority requirement is scheduled to be increased to seventy-five percent in December 2006. ${ }^{87}$

The ICA "assigns a host of special responsibilities" 88 to a fund's independent directors, including annually approving the fund's advisory contract and principal underwriting agreement, ${ }^{89}$ annually selecting the fund's independent accountant, approving any $12 \mathrm{~b}-1$ distribution plan (concurrently with the fund's full board), ${ }^{90}$ and adopting procedures for transactions with affiliated funds and determining compliance therewith quarterly (concurrently with the fund's full board). ${ }^{91}$ The Supreme Court has characterized the role of independent fund directors as "independent watchdogs" for the interests of fund shareholders. ${ }^{92}$ No types of business entities are statutorily required to have independent directors other than investment companies registered under the ICA. ${ }^{93}$

Finally, as noted above, section 36(a) provides a general fiduciary duty applicable to officers, directors, investment advisers, and principal underwriters of investment companies. This duty has been characterized as a "reservoir of fiduciary obligations" available to deal with misconduct that is not specifically addressed in the ICA. ${ }^{94}$ Specifically, section 36(a) of the ICA provides as follows:

17.

84. 15 U.S.C. § 80a-2(a)(19) (2000). See also RoBERTSON, supra note 25, § 3.03[4], at 3-16 \&

85. Id. § 3.03[1], at 3-12.

86. $I d$.

87. Investment Company Governance Release, supra note 15, at*17. See also 17 C.F.R. $\S$ $270.0-1(\mathrm{a})(7)$ (2005); ROBERTSON, supra note $25, \S 3.03$ [1], at 3-13. I say it is "scheduled" to be increased to seventy-five percent and not that it "will" be increased because a federal appellate court recently found that, in adopting the rule, the SEC violated the Administrative Procedure Act and remanded the matter to the SEC for further consideration. Chamber of Commerce v. SEC, 412 F.3d 133, 144 (D.C. Cir. 2005).

88. Burks v. Lasker, 441 U.S. 471, 486 (1979).

89. 15 U.S.C. $\S 80 \mathrm{a}-15$ (c) $(2000)$.

90. Id.

91. 17 C.F.R. § 270.17a-7(e) (2005). See also RoBERTSOn, supra note 25, § 3.01, at 3-4 to -5.

92. See Burks, 441 U.S. at $482-83$.

93. ROBERTSON, supra note $25, \S 3.01$, at 3-3.

94. Steadman v. SEC, 603 F.2d 1126, 1141-42 (5th Cir. 1979) (quoting Brown v. Bullock, 194 F. Supp. 207, 238-39 n.1 (S.D.N.Y. 1961), aff'd, 294 F.2d 415 (2d Cir. 1961)), aff'd, 450 U.S. 91 (1981); Strougo v. Scudder, Stevens \& Clark, Inc., 964 F. Supp. 783, 798 (S.D.N.Y. 1997) (same). 
The [SEC] is authorized to bring an action in the proper district court of the United States, or in the United States court of any territory or other place subject to the jurisdiction of the United States, alleging that a person serving or acting in one or more of the following capacities has engaged within five years of the commencement of the action or is about to engage in any act or practice constituting a breach of fiduciary duty involving personal misconduct in respect of any registered investment company for which such person so serves or acts-

(1) as officer, director, member of any advisory board, investment adviser, or depositor; or

(2) as principal underwriter, if such registered company is an open-end company, ${ }_{95}$ unit investment trust, or face-amount certificate company.

Section 36(a) does not provide for an express private cause of action. Courts, however, have recognized an implied private cause of action. ${ }^{96}$

Obviously, in a section 36(a) action by either the SEC or a private party, the meaning of "a breach of fiduciary duty involving personal misconduct" is key. This language raises two interpretive issues. First, what fiduciary duties do the enumerated parties owe to an investment company? Second, what sort of breach "involves personal misconduct"? Each of these issues is discussed in detail below.

\section{IV. "BREACH OF FIDUCIARY DUTY” UNDER SECTION 36(A)}

Implicit in the language of section 36(a) is a recognition by Congress that the officers, directors, investment adviser, and principal underwriter of an investment company owe the company fiduciary duties. ${ }^{97}$ Otherwise, section 36(a) would be superfluous; i.e., if no fiduciary duties are owed, it makes no sense to prohibit their breach. As Justice Frankfurter noted in SEC v. Chenery Corp., to conclude that one party owes another party fiduciary duties "gives direction to further inquiry. . . What obligations does [the party] owe as a fiduciary?" 98 The ICA is silent on this issue with respect to section 36(a).

95. 15 U.S.C. $\S 80 a-35$ (a) (2000).

96. See FRANKEL \& SCHWING, supra note $44, \S 34.03$, at 36-48 to -49 ("Substantially all courts now agree that section 36(a) does support an implied private right of action for breach of fiduciary duty involving personal misconduct in violation of section 36(a).").

97. See Tannenbaum v. Zellar, 552 F.2d 402, 416 (2d Cir. 1977) (stating that section 36 "established a federal standard of fiduciary duty in dealings between a mutual fund and its adviser"); Fogel v. Chestnutt, 533 F.2d 731, 745 (2d Cir. 1975) (stating that the ICA "implicitly established a federal standard of fiduciary duty in respect of dealings between a mutual fund and its adviser").

98. 318 U.S. 80, 85 (1943). 


\section{A. Legislative History and Case Law}

The legislative history of section 36(a) provides only limited guidance as to what fiduciary duties are owed. As originally enacted, the standard for a violation of section 36 was "gross misconduct or gross abuse of trust." 99 In 1970, however, Congress amended section 36 to change this standard to the current "breach of fiduciary duty involving personal misconduct" standard. ${ }^{100}$ According to the Senate Committee report on the underlying bill, the change was necessary because "the highly punitive overtones of the existing section, together with the injunctive penalty, seriously impairs the ability of the courts to deal flexibly and adequately with wrongdoing by certain affiliated persons of investment companies." 101 The report also stated that the standard encompassed "conduct which violates prevailing standards of fiduciary duty involving personal misconduct." ${ }^{\text {"102 }}$ Because there are no other relevant portions of legislative history on this issue from the 1970 amendment, all the legislative history tells us is that in the opinion of the Senate Committee, the duties owed are something greater than refraining from engaging in gross misconduct or gross abuse of trust, and they encompass fiduciary duties prevailing in 1970.

The courts have not provided much guidance either. Only a handful of cases address in any detail the issue of what fiduciary duties are owed for purposes of section 36(a). Three early circuit court decisions, Moses v. Burgin, ${ }^{103}$ Fogel v. Chestnutt, ${ }^{104}$ and Tannenbaum v. Zeller, ${ }^{105}$ explore the issue. Each of these cases arose out of the alleged failure of mutual funds to "recapture" a portion of commissions paid by the funds to securities brokers for executing trades for the funds' portfolios. At the time, the securities exchanges set brokerage commissions and disallowed discounts and rebates. ${ }^{106}$ Because mutual funds engaged in large and frequent trades generating large and frequent brokerage commissions, brokers coveted their business. ${ }^{107}$ Hence, to land the business, brokers were willing to work around the anti-rebate rules by allowing so-called

\footnotetext{
99. Investment Company Act of 1940, Pub. L. No. 76-768, § 36, 54 Stat. 841, 841 (1940).

100. Investment Company Amendments Act of 1970, Pub. L. No. 91-547, § 36, 84 Stat. 1413, 1429 (1970).

101. S. REP. No. 91-184, at 36 (1969) [hereinafter Senate Report].

102. Id.

103. 445 F.2d 369 (1st Cir. 1971).

104. 533 F.2d 731 (2d Cir. 1975).

105. 552 F.2d 402 (2d Cir. 1977).

106. See Moses, 445 F.2d at 372 (discussing prevention of direct cash refunds to the customer).

107. Id.
} 
customer-directed give-ups. ${ }^{108}$ Under this system, a fund's investment adviser would direct a trade-executing broker to pay a portion of the resulting brokerage commission, "sometimes as much as $75 \%$, ," broker who, for example, had sold shares of the fund to investors. ${ }^{110}$ This would reduce or eliminate the amount the adviser-underwriter had to pay to this second broker as compensation for selling fund shares. ${ }^{111}$

According to the 1966 SEC report, Public Policy Implications of Investment Company Growth (PPI), ${ }^{112}$ four adviser-underwriters, through the use of broker subsidiaries, were able to recapture these give-ups for the benefit of the fund without running afoul of the anti-rebate rules. ${ }^{113}$ The report also stated that "[u]nder existing commission rate structures, mutual fund shareholders could derive greater benefits from their brokerage commissions if the give-up portions of the commissions were transmitted to the funds themselves or their adviser-underwriters for the purpose of reducing management costs."114 This revelation spawned a large number of shareholder derivative suits brought on behalf of mutual funds that were not recapturing give-ups for the benefit of their funds against directors, investment advisers, and underwriters of the funds. ${ }^{115}$

Moses involved a shareholder derivative action against directors and officers of the mutual fund Fidelity Fund, Inc., and the fund's investment adviser and underwriter. ${ }^{116}$ The plaintiff asserted that Fidelity "could, and should, have recovered a portion of the brokerage commissions it was obliged to pay." 117 Because it did not, the plaintiff claimed that the defendants were liable under ICA section $36 .{ }^{118}$ Specifically, the plaintiff claimed that the fund's board never considered possible methods to recapture commissions "because relevant information regarding them was improperly withheld from the unaffiliated directors by the Management defendants." "119 The trial court dismissed the claim, finding that the fund directors based their decision not to pursue recapture on

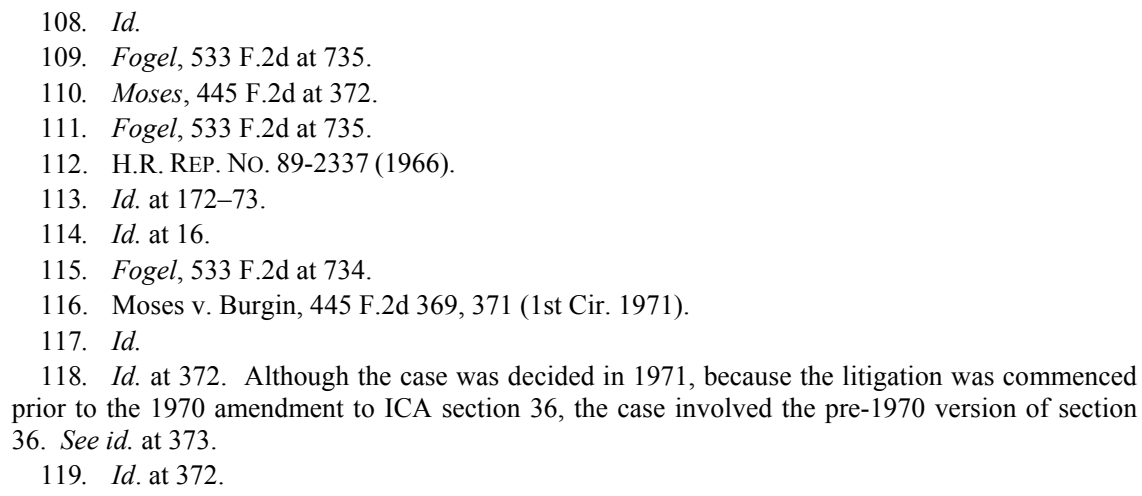

118. Id. at 372. Although the case was decided in 1971, because the litigation was commenced prior to the 1970 amendment to ICA section 36, the case involved the pre-1970 version of section 36. See id. at 373 .

119. Id. at 372 . 
"sound business and legal reasons" $" 120$ and therefore were not in breach of any fiduciary duty. ${ }^{121}$

The First Circuit disagreed. ${ }^{122}$ The court noted that one of the primary reasons Congress enacted the ICA was because of inherent conflicts of interests in the structure of investment companies. ${ }^{123}$ According to the court, the ICA responded to this problem by requiring that investment company boards include "unaffiliated, that is, independent, watchdog directors." 124 Hence, the court concluded that the fund's adviser and fund directors affiliated with the adviser "were under a duty of full disclosure of information to these unaffiliated directors in every area where there was even a possible conflict of interest between their interests and the interests of the fund." 125 The court further stated,

Except where it may be fairly assumed that every unaffiliated director will have such knowledge, effective communication is called for. And, in testing that assumption, it must be borne in mind that they are not full time employees of the fund and it may be-as with Fund's unaffiliated directors - that neither their activities nor their experience are primarily connected with the special and often technical problems of fund operation. If management does not keep these directors informed they will not be in a position to exercise the independent judgment that Congress clearly intended. The only question can be whether the matter is one that could be thought to be of possible significance.

Here, the court found that the adviser and affiliated directors were aware of the recapture issue, "that they knew it to be in an area where there was a conflict between their personal interests and the direct interests of the [f] und treasury, and that they did not inform the

120. Moses v. Burgin, 316 F. Supp. 31, 44 (D. Mass. 1970), rev'd, 445 F.2d 369 (1st Cir. 1971).

121. See id. at 55 .

122. 445 F.2d at 377.

123. Id. at 376 .

124. Id. As enacted in 1940 , the ICA required that at least " $40 \%$ of the directors on a fund's board be 'unaffiliated' with the fund" or the fund's investment adviser. See ROBERTSON, supra note $25, \S 3.02$, at 3-8. An unaffiliated director includes a person who is not an officer or employee of the fund, in a control relationship with the fund, or an investment adviser of the fund. 15 U.S.C. § 80a2(a)(3) (2000). See also ROBERTSON, supra note 25, § 3.03[4], at 3-17 to -18. In 1970, the ICA was amended to change the unaffiliated director requirement to an independent director requirement. See $i d$. $\S 3.02$, at 3-8. The concept of independent director is stricter than the concept of unaffiliated director; it excludes affiliates of the fund as well as affiliates of the fund's investment adviser and members of their immediate families. See supra text accompanying notes 83-85 for a discussion of the definition of independent director.

125. Moses, 445 F.2d at 376.

126. Id. at 377 . 
unaffiliated directors or submit it to their consideration."127 Thus, the court concluded that the adviser and affiliated directors breached this disclosure duty and were therefore liable under ICA section $36 .{ }^{128}$ The court concluded, however, that the unaffiliated directors were not liable because there was no evidence that they had knowledge of the possibility of recapture, a conflict of interest in the matter, or a duty to discover and explore the issue on their own. ${ }^{129}$

Fogel involved a shareholder derivative action by two shareholders of the mutual fund American Investors Fund against the fund's investment adviser and four fund directors affiliated with the investment adviser. $^{130}$ In accordance with Moses, the plaintiffs alleged that the defendants breached fiduciary duties owed to the fund by failing to inform the fund's independent directors of the possibility of recapture. ${ }^{131}$ The Second Circuit adopted the duty of disclosure articulated by the First Circuit in Moses. ${ }^{132}$

In the case, the defendants asserted that the unaffiliated directors were aware of the recapture issue and had been sent a copy of the PPI but were opposed to establishing the requisite broker subsidiary to enable recapture. ${ }^{133}$ The court found, however, that there had been ineffective communication of the issue to the unaffiliated directors largely because Stanley Sabel, an affiliated director of the fund and general counsel of the adviser, incorrectly advised the fund's directors that the SEC's recommendations about recapture did not apply to the fund. ${ }^{134}$ The court thus concluded that the affiliated directors were liable for breach of the Moses duty to disclose. ${ }^{135}$ The court stated,

The minimum requirement to enable the Fund's independent directors to discharge these [disclosure] duties with respect to recapture was a careful investigation of the possibilities performed with an eye eager to discern them rather than shut against them, and, if these possibilities were found to be real, a weighing of their legal difficulties and their economic pros and cons. It would have been still better to have the investigation of recapture methods and their legal consequences performed by disinterested counsel furnished to the independent

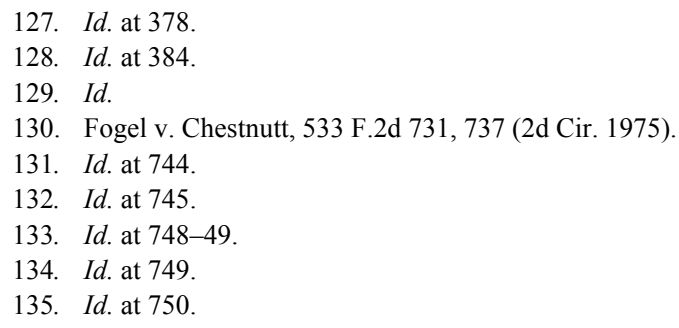


directors. If this had been done and the independent directors had concluded that, because of legal doubts, business considerations or both, the Fund should make no effort at recapture, we would have a different case. ${ }^{136}$

Tannenbaum involved a shareholder derivative action by a shareholder of the mutual fund Chemical Fund Inc. against the fund's investment adviser and the vice-chairman of the fund's board of directors. ${ }^{137}$ The plaintiff alleged that "the defendants breached their fiduciary duties to the Fund in their dealings with the independent directors regarding recapture." 138 The court noted that section 36 "established a federal standard of fiduciary duty in dealings between a mutual fund and its adviser"139 and that these duties were "at least as stringent as those at common law."140 The court then reviewed the Moses and Fogel decisions and agreed that ICA section 36 imposed a duty to disclose. ${ }^{141}$ The court described the duties of fund directors in the recapture context as follows:

[T] he decision to forego recapture here did not violate the fiduciary obligations of either the Fund's adviser or directors under section 36 of the Investment Company Act if the independent directors (1) were not dominated or unduly influenced by the investment adviser; (2) were fully informed by the adviser and interested directors of the possibility of recapture and the alternative uses of brokerage; and (3) fully aware of this information, reached a reasonable business decision to forego recapture after a thorough review of all relevant factors. ${ }^{142}$

The court applied these three prongs to the case at bar and concluded that all three prongs were met. ${ }^{143}$ Specifically, the court found that:

[t]here was full disclosure by the Fund's adviser as to the possibilities of recapture and the methods available to accomplish it. All material dealing with the question was placed before the independent directors and fully considered by them. They were correctly advised by counsel as to the applicable legal standards. They carefully weighed the relative advantages and disadvantages of recapture and the economic

136. Id. at 749-50 (footnote omitted).

137. Tannenbaum v. Zeller, 552 F.2d 402, 404, 411 (2d Cir. 1977).

138. Id. at 413 .

139. Id. at 416 .

140. Id. at 416 n. 20

141. Id. at 418 .

142. Id. at $418-19$.

143. Id. at 428 . 
pros and cons involved. Their decision to forego recapture was a reasonable business judgment. ${ }^{144}$

Hence, the court found that the defendants did not violate ICA section $36 .^{145}$

In the 1980 case Cambridge Fund, Inc. v. Abella, ${ }^{146}$ the court extended the Moses-Fogel-Tannenbaum line of cases. In the case, Cambridge Fund, Inc., brought an action to recover amounts paid by the fund to University Management Corporation; its adviser, Frank Abella, an affiliated director of the fund; and Robert Fredricks, an unaffiliated director of the fund, in indemnifying University Management and Abella for legal expenses they incurred in connection with an SEC investigation. ${ }^{147}$ The court reviewed Moses, Fogel, and Tannebaum and held that the duty to disclose articulated in that line of cases extended beyond the recapture issue. ${ }^{148}$ Hence, the court held that University Management and Abella "had a similar duty of disclosure with respect to the Fund's payment of their legal expenses" because the situation involved potential conflicts of interest. ${ }^{149}$ The court found that University Management and Abella breached this duty with respect to the indemnification issue because information relating thereto "was presented by [University] Management and Abella in such a one-sided and incomplete manner that it discouraged any meaningful, independent evaluation of the indemnification request by the unaffiliated directors." The court also held that Fredricks could be liable either if he was on notice of the issue and failed to explore it on his own, or if after his independent and thorough review of the issue he "failed to exercise reasonable business judgment" in deciding how to respond. ${ }^{151}$ The court found that Fredricks was not liable under this standard. ${ }^{152}$

The fund also sought to recover from Abella for personally trading in securities that the fund was also trading. ${ }^{153}$ With respect to this claim, the court held "that defendant Abella had, under [s]ection 36(a) of the

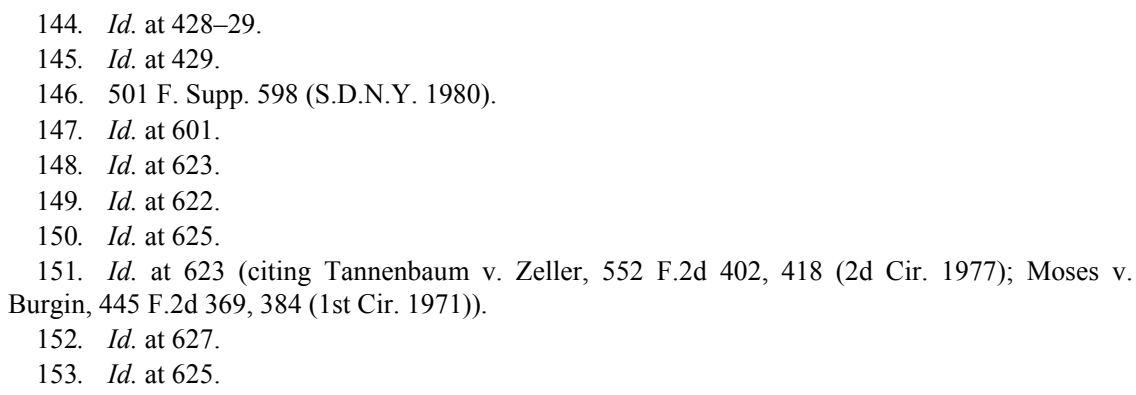


[Investment Company] Act, a duty to disclose to the independent directors any trading he did in securities being traded in simultaneously by the investment company." 154 The court based this holding on legislative history of the ICA that indicated a congressional concern with respect to simultaneous trading by a director and a fund. ${ }^{155}$ The court also based its holding on "the recognition that the independent directors were intended to be 'independent watchdogs' and that therefore full effective and neutral disclosure must be made to them as to all issues relating to the management of the fund or its assets and as to which there are potential conflicts of interest." 156 The court found that Abella did not knowingly breach this disclosure duty, reasoning that Abella's failure to disclose his simultaneous trading resulted from his belief that his trading did not give rise to conflicts of interest because the trades involved only a few hundred shares. ${ }^{157}$

In addition to the above line of cases with respect to the duty to disclose, a handful of cases touch on exactly what fiduciary duties are owed under ICA section 36(a). The Seventh Circuit mentioned the issue in the 1972 case, SEC v. Advance Growth Capital Corp. ${ }^{158}$ In this case, the SEC alleged, among other things, that two directors of Advance Growth, an investment company, violated section 36 of the ICA when they caused Advance Growth to engage in "certain allegedly improper transactions with affiliated companies." litigation prior to the 1970 amendments to section 36, the district court applied the old "gross misconduct or gross abuse of trust" standard and found no violation by the directors. ${ }^{160}$ The Seventh Circuit affirmed the district court on this point. ${ }^{161}$ In doing so, it acknowledged in a footnote that the standard under section 36 had changed since commencement of the case and stated that "[w]e are aware ... that the provisions of the [ICA] impose fiduciary obligations of the highest order upon persons who control investment companies."162

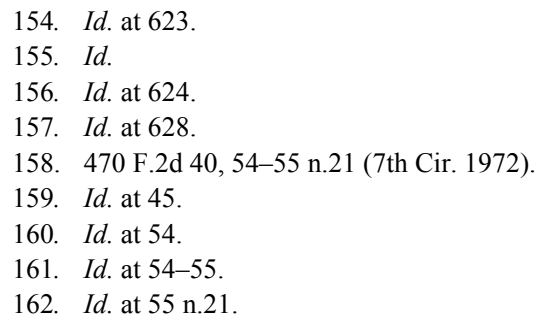


In the 1975 case Gafland v. Chestnutt, ${ }^{163}$ a shareholder brought a derivative action against the mutual fund American Investors Fund. ${ }^{164}$ The suit alleged, among other things, that an affiliated director of the fund improperly influenced the other fund directors to approve increasing the funds expense ratio. ${ }^{165}$ In ruling in favor of the plaintiff, the court mentioned in dicta that "[t]he directors of the Fund held a position of trust and confidence with respect to the Fund's shareholders, and owed them the obligations commonly associated with fiduciaries." 166 The court also stated "that the applicable standard of fiduciary duty was a matter of federal law incorporating wherever appropriate equitable safeguards long known to the common law." $" 167$

In the 1996 case Seidel $v$. Lee, ${ }^{168}$ plaintiff, a shareholder of ML-Lee Acquisition Fund, L.P., brought a class action suit against the fund, its investment adviser, underwriter, administrator, and general partners alleging, among other things, that the defendants violated ICA section 36(a) by recommending or approving allegedly unlawful transactions engaged in by the fund. ${ }^{169}$ In overruling a motion to dismiss for failure to state a claim, the court held that "[r]ecommending or approving a transaction without determining if it is a proper transaction would clearly be a breach of the [general partner's] fiduciary duties."

In the 2001 case, Goldstein v. Lincoln National Convertible Securities Fund, Inc., the plaintiff brought an action against the fund and its board of directors to set aside the election of directors. ${ }^{171}$ The plaintiff claimed that the defendants breached fiduciary duties owed under section 36(a) and state law "by enforcing an invalid advance notice deadline for submission of shareholder nominations and proposals and inequitably interfering with the shareholders' right to vote for directors." ${ }^{172}$ The court stated that ICA section 36(a) "imposes a federal standard for fiduciary obligations owed to shareholders by directors and other officers of mutual funds." 173 It then quoted the Tannenbaum court's statement

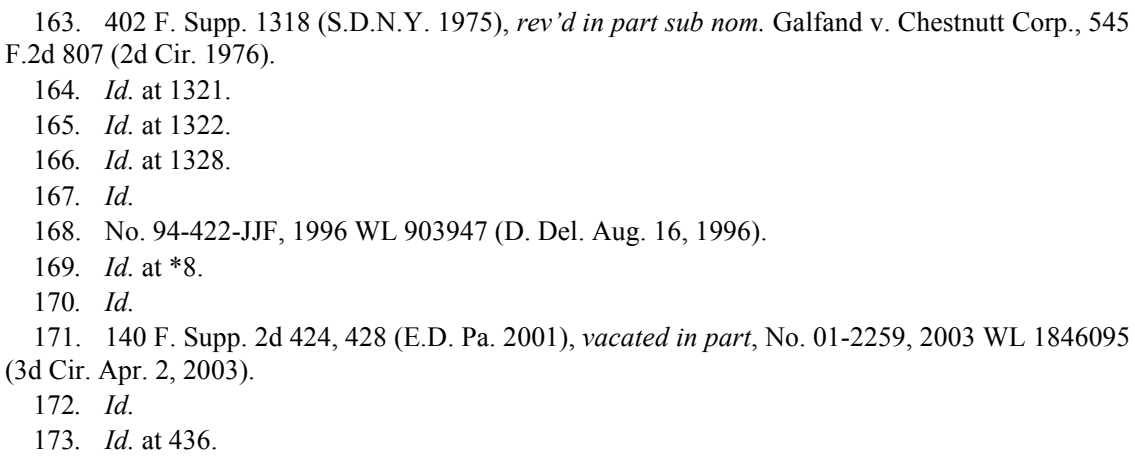


that the fiduciary duties owed under ICA section 36(a) are "'at least as stringent as those at common law" "174 and the reference in the legislative history of ICA section 36(a) to " "prevailing standard of fiduciary duty involving personal misconduct." "175 The court, however, did not address the section 36(a) claim because Congress relied on "prevailing standards" and the parties did not brief the issue of whether the defendants violated section 36(a). ${ }^{176}$ Instead, it addressed the breach of fiduciary duty claim under state law. ${ }^{177}$

Summing up the limited case law on the issue, section 36(a) imposes a federal standard of fiduciary duties. These duties are at least as stringent as those under common law and, at least according to one court, are of the highest order. These duties include an obligation by a fund's investment adviser and affiliated directors to make full disclosure to the fund's unaffiliated directors with respect to issues that involve a potential conflict of interest between the adviser and the fund. These duties also include an obligation by a fund's unaffiliated directors, if on notice of a potential conflict-of-interest issue, to investigate the issue. Finally, a decision by unaffiliated directors with respect to a potential conflict-ofinterest issue must constitute a reasonable business judgment.

\section{B. Need for Further Development}

Obviously, the section 36(a) fiduciary duty standard is not well defined. In light of the mutual fund scandal and attendant flood of litigation, it needs further development. Clarification is not necessarily needed for a section 36(a) claim against an investment adviser that engaged in the type of conduct described by Spitzer in his complaint against Canary. An investment adviser that has knowingly allowed traders to engage in late trading and market timing in exchange for indirect payments to the adviser has breached a fiduciary duty to the fund regardless of whether the duty is defined broadly or narrowly.

But what about less egregious or merely questionable mutual fund behavior? Examples abound. Take the common practice by advisers of charging funds marketing and distribution fees that are used in part for advertising and promotional materials to attract new investors. ${ }^{178}$ The

\footnotetext{
174. Id. (quoting Tannenbuam v. Zeller, 552 F.2d, 402, $416 \mathrm{n} .20$ (2d Cir. 1977)).

175. Id. (quoting S. REP. No. 90-3724, at 34 (1968)). See also text accompanying note 102.

176. Id. at 436-37.

177. Id. at 437 .

178. See Pui-Wing Tam, Some Closed Funds Charge for Marketing, WaLl St. J., Dec. 9, 1998, at $\mathrm{C} 1$ (explaining practice of $12 \mathrm{~b}-1 \mathrm{fee}$ ).
} 
thinking goes that because of economies of scale, attracting more assets lowers the expenses paid as a percentage of assets by the fund and thus benefits all fund shareholders. ${ }^{179}$ Funds can become too big, and hence many funds close to new investors before reaching this point. ${ }^{180}$ Some of these funds, however, continue to be charged the maximum possible marketing and distribution fees by their investment advisers. ${ }^{181}$ Critics contend that this is inappropriate. ${ }^{182}$ But, more importantly, have a fund board and adviser breached section 36(a) if they allow a closed fund to continue to be charged the maximum possible marketing fees? As another example, consider the number of mutual fund directorships held by a person. Outside of the mutual fund industry, it is rare for a person to serve on the board of more than ten corporations. ${ }^{183}$ Critics assert that even ten is too many because "individuals serving on too many boards lack time to adequately monitor a company's management, especially during tough times." 184 In the mutual fund industry, it is not uncommon for an individual to serve on a hundred or more boards. ${ }^{185}$ For example, The Wall Street Journal reported in March 2004 that Marvin Mann, the former chairman of a printer manufacturer, served on 292 mutual fund boards. ${ }^{186}$ Does an individual breach section 36(a) by serving on hundreds of mutual fund boards? Another example is the common practice of a fund's adviser hiring a sub-adviser to manage the fund's portfolio. In this situation, it is typical for the sub-adviser to agree to a breakpoint fee arrangement. ${ }^{187}$ If these fees end up being less than what the adviser charges the fund for portfolio management, ${ }^{188}$ has the adviser breached section 36(a)? One last example: Brokers recently have been accused of pushing clients to buy class B mutual fund shares when class

\footnotetext{
179. Id.

180. Id.

181. Id. See also Funds Charge Marketing Fees Though Portfolios Are Closed, Wall St. J., Aug. 5, 2003, at D2; Kara Scannell, Some Mutual-Fund Fees Face the Smell Test, WALl ST. J., Dec. 16,2003 , at $\mathrm{C} 1$.

182. See Funds Charge Marketing Fees Though Portfolios Are Closed, supra note 181; Scannell, supra note 181; Tam, supra note 178.

183. See Joann S. Lublin, Multiple Seats of Power: Companies Are Cracking Down On Number of Directorships Board Members Can Hold, WALl ST. J., Jan. 23, 2001, at B1 (explaining that public company investors have high expectations of board members).

184. Id.

185. See George Anders, Waking the Watchdog: As Scandals Mount, Boards of Mutual Funds Feel the Heat, WALL ST. J., Mar. 17, 2004, at A1.

186. Id.

187. Tom Lauricella, Mutual Funds Pocket the Fees Even as Costs Decline, Wall St. J., June 11,2004 , at C1. See RoBerTSON, supra note $25, \S 6.02$ [2], at 6-5 to -6 and text accompanying notes 38-42 for a discussion of breakpoint fee arrangements.

188. See Lauricella, supra note 187.
} 
A shares are more appropriate for the client. ${ }^{189}$ Some claim brokers do this because class B shares result in bigger commissions for the brokers. ${ }^{190}$ Assuming this is true, has a fund adviser breached section 36(a) if it is aware that brokers are improperly pushing class B shares of the fund and does nothing to stop them?

The ICA does not expressly prohibit any of the above practices, and from the perspective of the mutual fund industry there are likely legitimate reasons for engaging in all of them. However, as mentioned above, section 36(a) has been characterized as a "reservoir of fiduciary obligations" available to deal with misconduct by officers, directors, investment advisers, and principal underwriters of investment companies not addressed by the ICA. ${ }^{191}$ Hence, one could certainly argue that these practices violate section 36(a). Determining the circumstances under which any of these practices do or should constitute a violation of section 36(a) is beyond the scope of this Article. But at this point it should be obvious that additional guidance as to what constitutes a breach of fiduciary duty for purposes of section 36(a) is necessary, especially for the courts and attorneys dealing with the hundreds of lawsuits filed in the wake of the mutual fund scandal.

\section{Fiduciary Duties Under State Law}

So where does one turn for further guidance on defining the fiduciary duties owed under ICA section 36(a)? Because there generally is no federal law of fiduciary duty, ${ }^{192}$ an obvious place is state law. As mentioned above, each mutual fund is a separate legal entity organized under state law, typically as either a corporation or a business trust. ${ }^{193}$

189. Jonathan Clements, Why Brokers Want You to Buy 'B Shares' and Other Questionable Investments, WALL ST. J., July 14, 2004, at D1. See 17 C.F.R. § 270.12b-1(b)(2) (2005); ROBERTSON, supra note 25, § 7.01, at 7-11; Damato, supra note 53; Shultz, supra note 52. See also text accompanying notes 51-54 for a brief description of different classes of mutual fund shares.

190. Clements, supra note 189.

191. See supra note 94 and accompanying text.

192. See Santa Fe Indus. v. Green, 430 U.S. 462, 478-79 (1977) (refusing to recognize a federal law of fiduciary duty).

193. See supra note 25 and accompanying text. There are various considerations that drive the decision as to legal form, but in general "a business trust provides greater flexibility with respect to procedural matters and a corporation provides greater flexibility with respect to limitation of personal liability." Newman, supra note 25, at*5. See also Victoria E. Schonfeld \& Thomas M.J. Kerwin, Organization of a Mutual Fund, 49 Bus. LAw. 107, 114-16 (1993). As of 1997, the split was approximately fifty-fifty between funds organized as corporations and funds organized as business trusts. ROBERTSON, supra note $25, \S 2.02$, at 2-12. As to jurisdiction, Maryland has emerged as the preferred jurisdiction for funds organized as corporations. ROBERTSON, supra note $25, \S 2.02$, at 2-13. The reason for this popularity is that Maryland's corporations statute contains 
State corporate law imposes a well-developed body of fiduciary duties on directors of corporations, ${ }^{194}$ which a court could look to in defining fiduciary duties for purposes of ICA section 36(a). This body of law is relevant not only to funds organized as corporations but also to those organized as business trusts. This is because state courts have generally analogized the duties of trustees of business trusts to those of directors of corporations. ${ }^{195}$ The primary fiduciary duties owed by corporate directors under state law are the duty of care and the duty of loyalty. ${ }^{196}$ Each is discussed below.

\section{Duty of Care}

Broadly speaking, "the duty of care requires that directors exercise the care that a person in a like position would exercise under similar circumstances."197 For example, section 2-405.1 of the Maryland corporations statute entitled "Standard of Care Required of Directors" provides as follows:

A director shall perform his duties as a director, including his duties as a member of a committee of the board on which he serves:

(1) In good faith;

(2) In a manner he reasonably believes to be in the best interests of the corporation; and

(3) With the care that an ordinary prudent person in a like position would use under similar circumstances.

This is a typical formulation patterned after the pre-1998 version of section 8.30 of the Model Business Corporation Act (MBCA), on which

\footnotetext{
various provisions specifically tailored for investment companies. See Newman, supra note 25, at *5; Schonfeld \& Kerwin, supra at 115-16. A mutual fund organized as a business trust typically is established under the statutory trust laws of Delaware or the business trust laws of Massachusetts. Schonfeld \& Kerwin, supra at 115-16.

194. See generally Dennis J. Block et AL., The Business Judgment Rule: Fiduciary DUTIES OF CORPORATE DIRECTORS (5th ed. 1998).

195. See, e.g., Saminsky v. Abbot, 185 A.2d 765, 768 (Del. Ch. 1961); Richardson v. Clarke, 364 N.E. 2d 804, 806-07 (Mass. 1977); see also Norlin Corp. v. Rooney, Pace, Inc., 744 F.2d 255, 264 (2d Cir. 1984) ("A board member's obligation to a corporation and its shareholders has two prongs, generally characterized as the duty of care and the duty of loyalty."); ROBERTSON, supra note $25, \S 2.02[2]$, at 2-17.

196. BLOCK, supra note 194 , at 1.

197. Id. at 109 .

198. MD. CODE ANN., CORPS. \& ASS'NS § 2-405.1(a) (LexisNexis 1999).
} 
thirty-nine other jurisdictions have patterned their directors' standard-ofcare statutory provisions. ${ }^{199}$

The 1994 Corporate Director's Guidebook put out by the Business Law Section of the American Bar Association elaborates on the various components of the above language:

- in good faith-acting honestly; not to act, or cause the corporation to act, in an unlawful way; purporting to rely upon information that a director knows to be untrue will not be considered acting in good faith;

- care-expressing the need to pay attention and to act diligently and reasonably;

- ordinarily prudent person-incorporating the basic attributes of common sense, practical wisdom, and informed judgment;

- in a like position-recognizing that the nature and extent of the corporate director's role will vary depending upon such factors as the background and qualifications of the director, and the size, complexity, and location of the enterprise's activities;

- under similar circumstances - recognizing that the nature and extent of the oversight will vary, depending upon the corporation concerned and the factual situation presented;

- reasonably believes - establishing that the standard of conduct is objective, not subjective; and

- best interests of the corporation-emphasizing the corporate director's primary allegiance to the corporation.

The role of a corporation's board entails both decision-making and oversight functions. ${ }^{201}$ The decision-making function involves working with management to establish high-level corporate policy and strategic

199. 2 Model Business CoRporation ACT AnNOTATED $\S 8.30$, at 8-177 (3d ed. 2000) [hereinafter MBCA ANNOTATED]. In 1998, MBCA section 8.30 was amended to provide:

(a) Each member of the board of directors, when discharging the duties of a director, shall act: (1) in good faith, and (2) in a manner the director reasonably believes to be in the best interest of the corporation.

(b) The members of the board of directors or a committee of the board, when becoming informed in connection with their decision-making function or devoting attention to their oversight function, shall discharge their duties with the care that a person in a like position would reasonably believe appropriate under similar circumstances.

As of 2002, four states (Hawaii, Iowa, Maine, and Mississippi) had adopted amended section 8.30. Id. at $8-177$.

200. Committee on Corporate Laws, Corporate Director's Guidebook-1994 Edition, 49 Bus. LAW. 1243, 1252-53 (1994).

201. See Comm. on Corporate Laws, ABA Section of Bus. Law, Corporate Director's Guidebook: Fourth Edition, 59 BuS. LAW. 1057, 1063 (2004) [hereinafter 2004 Director's Guidebook]; see also 1 William E. KNEPPER \& DAN A. BAILEY, LiABILITy OF CORPORATE OFFICERS AND DIRECTORS $\S 1.02$ (7th ed. 2004). 
goals as well as making decisions with respect to such matters as hiring senior management and setting executive compensation. ${ }^{202}$ The oversight function consists of ongoing monitoring of the corporation's activities. $^{203}$ It does not require directors to engage in "a detailed inspection of day-to-day activities, but rather a general monitoring of corporate affairs and policies." ${ }^{204}$ The duty of care applies to both the decision-making and oversight functions. ${ }^{205}$

The seminal case on the oversight function is the 1963 Delaware Supreme Court decision Graham v. Allis-Chalmers Manufacturing Co. ${ }^{206}$ This case arose out of guilty pleas by Allis-Chalmers and four of its employees for violations of federal antitrust laws. ${ }^{207}$ In the case, plaintiffs brought a derivative suit against Allis-Chalmers's directors to recover damages to it resulting from these guilty pleas. ${ }^{208}$ The plaintiffs alleged that the directors were liable because they failed "to take action designed to learn of and prevent anti-trust activity on the part of any employees of Allis-Chalmers."209 The court found that the directors had no knowledge of the antitrust violations nor did they have reason to know. $^{210}$ The court then rejected plaintiffs' claim, stating that "absent cause for suspicion there is no duty upon the directors to install and operate a corporate system of espionage to ferret out wrongdoing which they have no reason to suspect exists." 211 The court did note, however, that if a director "has recklessly reposed confidence in an obviously untrustworthy employee, has refused or neglected cavalierly to perform his duty as a director, or has ignored either willfully or through inattention obvious danger signs of employee wrongdoing, the law will cast the burden of liability upon him." 212 The court found this not to be the case because the board addressed the situation promptly once it became aware of it. ${ }^{213}$

\footnotetext{
202. See 2004 Director's Guidebook, supra note 201, at 1063-64.

203. Id.

204. Francis v. United Jersey Bank, 432 A.2d 814, 822 (N.J. 1981) (citing Williams v. McKay, 18 A. 824,828 (N.J. Ch. 1889)).

205. See BLOCK, supra note 194, at 52 (stating that the duty of care applies to directors in the performance of their corporate duties).

206. 188 A.2d 125 (Del. 1963).

207. Id. at 127 .

208. Id

209. Id.

210. Id. at 129-30.

211. Id. at 130 .

212. Id.

213. Id.
} 
Chancellor Allen, a well-respected Delaware jurist, ${ }^{214}$ refined the duty of oversight as espoused in Allis-Chalmers in In re Caremark International Inc. Derivative Litigation. ${ }^{215}$ The opinion involved the Chancellor's review of a proposed settlement of a derivative suit against Caremark's board of directors. ${ }^{216}$ The derivative suit arose out of Caremark's payment of approximately $\$ 250$ million to various public and private parties under a plea agreement for alleged violations of federal and state laws by Caremark employees. ${ }^{217}$ The suit sought to recover this amount from the members of Caremark's board of directors on grounds that the directors breached their duty of care to Caremark in connection with the situation. ${ }^{218}$ Specifically, the suit claimed "that the directors allowed a situation to develop and continue which exposed the corporation to enormous legal liability and that in so doing they violated a duty to be active monitors of corporate performance." 219

In considering the merits of the claim, Chancellor Allen discussed Allis-Chalmers and concluded that the case should not be read broadly to mean "absent some ground giving rise to suspicion of violation of law, that corporate directors have no duty to assure that a corporate

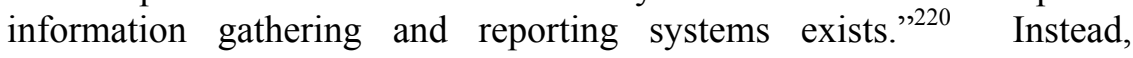
Chancellor Allen concluded that Allis-Chalmers "can be more narrowly interpreted as standing for the proposition that, absent grounds to suspect deception, neither corporate boards nor senior officers can be charged with wrongdoing simply for assuming the integrity of employees and the honesty of their dealings on the company's behalf." 221 Hence, to satisfy the duty to be reasonably informed, the directors have an affirmative duty to assure themselves

that information and reporting systems exist in the organization that are reasonably designed to provide to senior management and to the board itself timely, accurate information sufficient to allow management and the board, each within its scope, to reach informed judgments

\footnotetext{
214. 1 David A. Drexler, et al., Delaware Corporation LaW and Practice $§ 15.06[1]$ (2004).

215. 698 A.2d 959 (Del. Ch. 1996).

216. Id. at 960 .

217. Id. at $960-61$.

218. Id.

219. Id. at 967 .

220. Id. at 969 .

221. Id. (citing Graham v. Allis-Chalmers Mfg. Co., 188 A.2d 125, 130-31 (Del. 1963)).
} 
concerning both the corporation's compliance with law and its business performance. $^{222}$

Chancellor Allen concluded that failure by the board to do so "under some circumstances may, in theory at least, render a director liable for losses caused by non-compliance with applicable legal standards."223

\section{The Business-Judgment Rule and Raincoat Provisions}

Focusing on the duty of care in determining whether a bad decision by a director is actionable is misleading. This is because a director who fails to comply with the duty of care will not necessarily be liable to the corporation or its shareholders for resulting damages. ${ }^{224}$ To recover damages, before even getting to whether a director breached his duty of care, the plaintiff must overcome the business-judgment rule and likely a so-called "raincoat" provision in the corporation's articles or certificate of incorporation. ${ }^{225}$ Each of these hurdles is discussed below.

The business-judgment rule is a presumption applied by courts in reviewing business decisions by corporate directors. Under the rule, courts presume that decisions are made "on an informed basis, in good faith and in the honest belief that the action taken was in the best interests of the company. $" 226$ If a director is sued by a shareholder or the corporation for a business decision allegedly made in breach of the director's duty of care to the corporation, the court will examine the merits of the decision only if the plaintiff has proven facts that overcome the business-judgment rule presumption. "When applied, this principle operates both as a procedural rule of evidence and a substantive rule of law, in that if the plaintiff fails to rebut the presumption that the directors acted in good faith, in the corporation's best interest and on an informed basis, the business judgment standard protects both the directors and the decisions they make."227 Put simply, unless the presumption is rebutted,

\footnotetext{
222. Id. at 970 .

223. Id.

224. BLOCK, supra note 194, at 109.

225. See id. at $225-26$.

226. Aronson v. Lewis, 473 A.2d 805, 812 (Del. 1984), overruled on other grounds by Brehm v. Eisner, 746 A.2d 244 (Del. 2000). See also Yost v. Early, 589 A.2d 1291, 1298 (Md. Ct. Spec. App. 1991) (quoting Aronson, 473 A.2d at 812); BLOCK, supra note 194, at 5.

227. 2 MBCA ANNOTATED, supra note $199, \S 8.31$ official cmt. at 8-197 to -98. See also Citron v. Fairchild Camera \& Instrument Corp., 569 A.2d 53, 64 (Del. 1989) (explaining the rule and citing cases applying it).
} 
courts will not second guess business decisions by corporate directors, even if the decision proved disastrous. ${ }^{228}$

Courts have fashioned various formulations as to what a plaintiff must plead and prove to rebut the business-judgment rule presumption. ${ }^{229}$ For example, in the 1982 opinion, Joy v. North, the court stated that the presumption would be overcome if the plaintiff proved that the "corporate decision lacks a business purpose, is tainted by a conflict of interest, is so egregious as to amount to a no-win decision, or results from an obvious and prolonged failure to exercise oversight or supervision., ${ }^{, 30}$ More recently, in its 2003 opinion In re Walt Disney Company Derivative Litigation, the Delaware Chancery Court stated as follows:

Plaintiffs may rebut the presumption that the board's decision is entitled to deference by raising a reason to doubt whether the board's action was taken on an informed basis or whether the directors honestly and in good faith believed that the action was in the best interests of the corporation. Thus, plaintiffs must plead particularized facts sufficient to raise (1) a reason to doubt that the action was taken honestly and in good faith or (2) a reason to doubt that the board was adequately informed in making the decision. ${ }^{231}$

The rationale behind the business-judgment rule is based on five grounds. ${ }^{232}$ First, everyone makes mistakes, including well-intentioned, informed directors. The business-judgment rule, however, in the great majority of cases, prevents a court from second guessing with the benefit of hindsight a decision that turned out to be a mistake. Hence, the rule "encourages competent individuals to become directors who otherwise might decline for fear of personal liability." 233

Second, building a successful business entails taking risks. "[B]ecause potential profit often corresponds to the potential risk, it is very much in the interest of shareholders that the law not create incentives for overly cautious corporate decisions. ${ }^{234}$ Hence, because the business-judgment rule generally shields directors from personal

228. See 1 KNEPPER \& BAILEY, supra note $201, \S 2.07$, at 2-17 to -18 .

229. Id. $\S 2.10$, at $2-25$.

230. 692 F.2d 880, 886 (2d Cir. 1982) (citations omitted).

231. 825 A.2d 275, 286 (Del. Ch. 2003).

232. BLOCK, supra note 194, at 12.

233. Air Line Pilots Ass'n v. UAL Corp., 717 F. Supp. 575, 582 (N.D. Ill. 1989). See also BLOCK, supra note 194, at 12.

234. Joy, 692 F.2d at 886. 
liability, it allows them to "honestly assess risk and reward and accept for the corporation the highest risk adjusted returns available that are above the firm's cost of capital." 235 Essentially, it takes out of the equation director concerns about personal liability if the decision turns out poorly.

Third, most courts do not have the business expertise to evaluate the merits of a decision. ${ }^{236}$ Hence, the business-judgment rule appropriately prevents the courts from reviewing the merits of most business decisions. "[D]irectors are, in most cases, more qualified to make business decisions than are judges." 237 Further, courts have acknowledged that the courtroom is a less-than-ideal setting to evaluate a business decision. ${ }^{238}$ This is because " $[t]$ he circumstances surrounding a corporate decision are not easily reconstructed in a courtroom years later, since business imperatives often call for quick decisions, inevitably based on less than perfect information." 239 Therefore, "a reasoned decision at the time made may seem a wild hunch viewed years later against a background of perfect knowledge." ${ }^{240}$ Hence, a court is just not in a position to second guess the merits of a director's business decision.

Fourth, the business-judgment rule prevents shareholders from impinging on directors' power and authority to manage the business and affairs of corporations. "If shareholders are granted the right to demand frequent judicial review of board decisions, the result would be to transfer ultimate decision-making authority from the board to any shareholder who is willing to sign a complaint." 241

Fifth, courts have noted that if shareholders are unhappy with director decisions, they can replace the directors. ${ }^{242}$ Therefore, substantive review of a director's business decision is not necessary.

Finally, note that the business-judgment rule only applies to business decisions. ${ }^{243}$ Thus, a failure by directors to act is not protected by the business-judgment rule unless the directors made a conscious decision

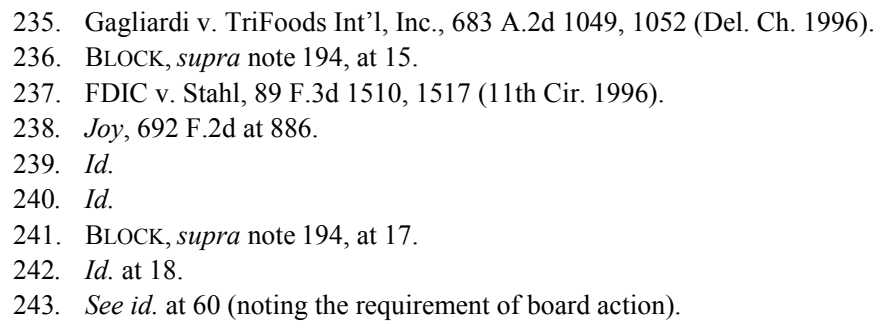


not to act. ${ }^{244}$ If they simply failed to act because they never considered the issue, business-judgment rule protection does not apply. ${ }^{245}$

Reinforcing the business-judgment rule, a raincoat provision is a provision of a corporation's articles or certificate of incorporation adopted under a director-protection statute that limits or eliminates the liability of directors for a breach of the duty of care. ${ }^{246}$ For example, subsection (b)(7) of section 102 of the Delaware General Corporation Law allows a corporation to include in its certificate of incorporation "[a] provision eliminating or limiting the personal liability of a director to the corporation or its stockholders for monetary damages for breach of fiduciary duty as a director." 247 The provision, however, may not limit or eliminate director liability in the following circumstances:

(i) For any breach of the director's duty of loyalty to the corporation or its stockholders; (ii) for acts or omissions not in good faith or which involve intentional misconduct or a knowing violation of law; (iii) under $\S 174$ of this title [provides for director liability for the wrongful payment of dividends or redemption of stock]; or (iv) for any transaction from which the director derived an improper personal benefit. $^{248}$

In addition to Delaware, forty-three states have raincoat provisions in their corporate statutes. ${ }^{249}$ Articles provisions taking full advantage of these statutory provisions are almost universally included in the articles or certificates of newly incorporated companies, and most companies that incorporated prior to the enactment of these statutory provisions have amended their articles to take full advantage. ${ }^{250}$ Hence, it is now virtually impossible to prevail on a claim for money damages against a director for a decision made solely in breach of the director's duty of care. This is because to do so the plaintiff would have to overcome both

\footnotetext{
244. Id. See also Aronson v. Lewis, in which the court stated that it should be noted that the business judgment rule operates only in the context of director action. Technically speaking, it has no role where directors have either abdicated their functions, or absent a conscious decision, failed to act. But it also follows that under applicable principles, a conscious decision to refrain from acting may nonetheless be a valid exercise of business judgment and enjoy the protections of the rule. 473 A.2d 805, 813 (Del. 1984)

245. BLOCK, supra note 194 , at 60.

246. See id. at 226.

247. Del. Code ANN. tit. 8, § 102(b)(7) (2001).

248. Id.

249. See 1 MBCA ANNOTATED, supra note 199, § 2.02, at 2-31.

250. 2 KNEPPER \& BAILEY, supra note 201, § 16.03, at 16-5.
} 
a raincoat provision and the business-judgment rule presumption. ${ }^{251}$ Simply put, a plaintiff would need to plead and prove that the decision involved something more than a mere breach of the duty of care, such as a breach of the duty of loyalty or bad faith. ${ }^{252}$

\section{Duty of Loyalty}

In addition to a duty of care, state corporate law imposes on corporate directors a duty of loyalty. The Corporate Director's Guidebook describes the duty of loyalty as follows:

The duty of loyalty requires a director's conduct to be in good faith and in the best interests of the corporation - and not in the director's own interest or in the interest of another person (such as a family member) or an organization with which the director is associated. Simply put, a director should not use the director's corporate position for personal profit or gain or for other personal or noncorporate advantage.

The duty of loyalty is implicated whenever a director has a direct or indirect financial or personal interest in a transaction involving the corporation. ${ }^{254}$ The duty of loyalty, however, does not establish a blanket

251. BLOCK, supra note 194, at 229.

252. 2 KNEPPER \& BAILEY, supra note $201, \S 16.03$, at 16-8.

253. 2004 Director's Guidebook, supra note 201, at 1070. The Delaware Supreme Court established the seminal formulation of the corporate director duty of loyalty in Guth v. Loft, Inc.:

Corporate officers and directors are not permitted to use their position of trust and confidence to further their private interests. While technically not trustees, they stand in a fiduciary relation to the corporation and its stockholders. A public policy, existing through the years, and derived from a profound knowledge of human characteristics and motives, has established a rule that demands of a corporate officer or director, peremptorily and inexorably, the most scrupulous observance of his duty, not only affirmatively to protect the interests of the corporation committed to his charge, but also to refrain from doing anything that would work injury to the corporation, or to deprive it of profit or advantage which his skill and ability might properly bring to it, or to enable it to make in the reasonable and lawful exercise of its powers. The rule that requires an undivided and unselfish loyalty to the corporation demands that there shall be no conflict between duty and self-interest. The occasions for the determination of honesty, good faith and loyal conduct are many and varied, and no hard and fast rule can be formulated.

The standard of loyalty is measured by no fixed scale.

5 A.2d 503, 510 (Del. 1939).

254. 2004 Director's Guidebook, supra note 201, at 1070. See also 1 KNEPPER \& BAILEY, supra note 201, § 4.02, at 4-4. HMG/Courtland Properties, Inc. v. Gray, 749 A.2d 94 (Del. Ch. 1999), provides a classic example of a so-called conflict-of-interest transaction. In this case, HMG sold real estate to NAF Associates. Id. at 101. The court found that two directors of HMG breached their duties of loyalty to HMG because they owned interests in NAF and the transaction was not entirely fair to HMG. Id. at 118. 
prohibition against transactions in which a conflict of interest exists. ${ }^{255}$ There is nothing inherently wrong with a corporation entering into a transaction with a director, and in many situations it may make good business sense for the corporation to do so. ${ }^{256}$ Hence, many states have enacted safe-harbor provisions that protect a transaction from challenge solely on the ground that it involves a director conflict of interest if after full disclosure regarding the conflict the transaction is approved by a majority of disinterested directors or shareholders. ${ }^{257}$ However, because of the obvious potential for abuse in these transactions, if a director is sued for breach of the duty of loyalty because the director entered into a conflict-of-interest transaction that did not receive the requisite disinterested director or shareholder approval, the burden will be on the director to prove the fairness of the transaction to the corporation. ${ }^{258}$

Neither the business-judgment rule nor an articles raincoat provision shields a director from liability for a breach of the duty of loyalty. If a plaintiff is able to plead and prove that a director breached the duty of loyalty, the court will conclude that the plaintiff has rebutted the business-judgment rule presumption. ${ }^{259}$

\section{Corporate Law Fiduciary Duties Owed by Officers}

Under state law, corporate officers generally owe the same fiduciary duties to the corporation and its shareholders as owed by directors. ${ }^{260}$ In twenty-nine states, this is pursuant to state statute. ${ }^{261}$ In other states, such as Delaware and Maryland, this is pursuant to state common law. ${ }^{262}$ In

\footnotetext{
255. BLOCK, supra note 194, at 266.

256. Id.

257. E.g., Del. Code AnN. tit. 8, § 144(a) (2001); Md. Code ANN., CorPs. \& Ass'NS § 2-419 (West 2003); MOdEL BUS. CORP. ACT $\S \S 8.60-8.63$ (1979).

258. MOdEL Bus. CORP. ACT § 8.61; BLOCK, supra note 194, at 268.

259. See Cinerama, Inc. v. Technicolor, Inc., 663 A.2d 1156, 1164 (Del. 1995) (explaining that the board of directors lost the presumptive protection by breaching its duty of care).

260. A. Gilchrist Sparks III \& Lawrence A. Hamermesh, Common Law Duties of Non-Director Corporate Officers, 48 BUS. LAW. 215, 217 (1992). See also 1 KNEPPER \& BAILEY, supra note 201, $\S 1.15$, at $1-53$ (stating that non-director officers are held to the same standard of care as directors).

261. The majority of these states have modeled their provisions on Section 8.42(a) of the MBCA ANNOTATED, which provides, "[a]n officer, when performing in such capacity, shall act: (1) in good faith; (2) with the care that a person in a like position would reasonably exercise under similar circumstances; and (3) in a manner the officer reasonably believes to be in the best interest of the corporation." 2 MBCA ANNOTATED, supra note 199, § 8.42(a), at 8-262, -266.

262. See Sparks \& Hamermesh, supra note 260, at 217 (compiling cases in multiple jurisdictions where courts have held that officers owe fiduciary duties to the corporation); see also Leavy v. Am. Fed. Sav. Bank, 764 A.2d 366, 372 (Md. Ct. Spec. App. 2000) ("Maryland courts have long recognized that a corporate officer may not use the corporate office or assets for personal gain."); 1 DREXLER, supra note $214, \S 14.02$, at 14-5.
} 
fact, officers may be held to a higher standard than directors. ${ }^{263}$ "[T] $]$ he duties of active officers of a corporation who devote all or most of their time to a corporation's business and who receive a salary as officers, are more extensive than those of directors who do not give the corporation daily attendance and who receive little or no salary."264

There is disagreement on whether the business-judgment rule applies to decisions of officers. ${ }^{265}$ Many cases state that the rule applies to "officers and/or directors." "266 These statements, however, typically appear in cases where the defendants are both directors and officers. ${ }^{267}$ Few courts have specifically addressed the issue of whether the businessjudgment rule presumption applies to a decision by a non-director officer, and the few that have are split. ${ }^{268} \mathrm{~A}$ federal court applying Delaware law stated that " $[\mathrm{t}] \mathrm{he}$ business judgment rule applies only to directors of a corporation and not to officers."269 A California appellate court has held likewise under California law. ${ }^{270}$ However, courts in Florida, ${ }^{271}$ Illinois, ${ }^{272}$ and New York $^{273}$ have stated that the businessjudgment rule applies to officers.

As for raincoat provisions, most states do not allow them to apply to anyone other than a corporate director. ${ }^{274}$ Maryland and a few other states, however, do allow corporations to adopt article provisions limiting or eliminating the liability of both officers and directors. ${ }^{275}$ Hence, depending on the state, an officer may or may not be protected by

263. See Sparks \& Hamermesh, supra note 260, at 218.

264. Id. at 219.

265. Id. at 230. See also Lawrence A. Hamermesh \& A. Gilchrist Sparks III, Corporate Officers and the Business Judgment Rule: A Reply to Professor Johnson, 60 Bus. LAW. 865 (2005); Lyman P.Q. Johnson, Corporate Officers and the Business Judgment Rule, 60 BUS. LAW. 439 (2005).

266. Sparks \& Hamermesh, supra note 260, at 229-30.

267. Id. at 230-36.

268. See 1 KNEPPER \& BAILEY, supra note 201 , § 2-1 ("[P]ublic policy and the little case authority that exists point in the direction of the same standards of care and business judgment for both directors and officers.").

269. Platt v. Richardson, No. 88-0144, 1989 WL 159584, at *2 (M.D. Pa. June 6, 1989).

270. Gaillard v. Natomas Co., 256 Cal. Rptr. 702, 711 (Cal. Ct. App. 1989).

271. See Amerifirst Bank v. Bomar, 757 F. Supp. 1365, 1376 (S.D. Fla. 1991) ("Under the business judgment rule officers and directors of a corporation are presumed to have acted properly and in good faith." (citing Int'l Ins. Co. v. Johns, 874 F.2d 1447, 1461 (11th Cir. 1989))).

272. Selcke v. Bove, 629 N.E.2d 747, 750 (Ill. App. Ct. 1994).

273. Estate of Detwiler v. Offenbecher, 728 F. Supp. 103, 148 (S.D.N.Y. 1989).

274. 2 KNEPPER \& BAILEY, supra note 201 , § 16.03 , at 16-3 to -4 .

275. See, e.g., MD. CODE ANN., CoRPS. \& Ass'NS § 2-405.2 (LexisNexis 1999); MD. CodE ANN., CTS. \& JUD. Proc., §5-418 (LexisNexis 2002); see also 2 KNEPPER \& BAILEY, supra note $201, \S 16-2$ (explaining that state legislation has been enacted since 1986 authorizing charter provisions that eliminate or restrict personal liability of directors, and sometimes officers, for money damages) 
the business-judgment rule and may or may not be protected by a raincoat provision.

\section{Fiduciary Duties Owed Under State Agency Law}

In addition to state corporate law, fiduciary duties are addressed under state agency law. "Agency is the fiduciary relation which results from the manifestation of consent by one person to another that the other shall act on his behalf and subject to his control, and consent by the other so to act." 276 The party on whose behalf action is to be taken is referred to as the principal, and the party who is to act is referred to as the agent. ${ }^{277}$ An agent owes various fiduciary duties to the principal. ${ }^{278}$ These duties include both a duty of care and a duty of loyalty. ${ }^{279}$ Restatement of the Law, Second, Agency section 379 provides that "[a] paid agent is subject to a duty to the principal to act with standard care and with the skill which is standard in the locality for the kind of work which he is employed to perform and, in addition, to exercise any special skill[s] . . he has." 280 The comments to this section indicate that this duty reflects a negligence standard. ${ }^{281}$ As for the duty of loyalty, Restatement of the Law, Second, Agency section 387 provides that "[u]nless otherwise agreed, an agent is subject to a duty to his principal to act solely for the benefit of the principal in all matters connected with his agency." 282

An agent also has a duty to provide information. ${ }^{283}$ Restatement of the Law, Second, Agency section 381 provides "[u]nless otherwise agreed, an agent is subject to a duty to use reasonable efforts to give his principal information which is relevant to affairs entrusted to him and which, as the agent has notice, the principal would desire to have and which can be communicated without violating a superior duty to a third person." "284 Finally, Restatement of the Law, Second, Agency section 425 provides as follows:

\footnotetext{
276. RestATEMENT (SECOND) OF AGENCY § 1 (1958).

277. Id.

278. Id. ch. 13, Topic 1, Introductory Note.

279. Id. $\S \S 379,387$.

280. Id. $\S 379$.

281. Id. §379 cmts. b-c.

282. Id. $\S 387$.

283. Id. $\S 381$.

284. Id.
} 
Unless otherwise agreed, an agent employed to make or to manage investments has a duty to the principal:

(a) to use care to invest promptly;

(b) to invest only in such securities as would be obtained by a prudent investor for his own account, having in view both safety and income, in the light of the principal's means and purposes; and

(c) to change investments in accordance with changes in the security of the investments or the condition of the principal, if his duties include management. ${ }^{285}$

Considering that there is no equivalent to the business-judgment rule or raincoat provisions under agency law, presumably it is easier for a plaintiff to prove a breach of fiduciary duty for which money damages are available under agency law rather than under corporate law. Note that corporate directors are not considered agents of their corporations. ${ }^{286}$ Officers and other corporate employees, however, are agents of the corporation. ${ }^{287}$

\section{Federal or State Law?}

Considering the well-developed body of state fiduciary duty law, the general lack thereof at the federal level, ${ }^{288}$ and references in the section 36(a) legislative history to "prevailing standards of fiduciary duty," 289 it seems obvious that state law should play a role in defining "breach of fiduciary duty" under ICA section 36(a). The question then becomes to what extent should state law be incorporated into section 36(a)? ${ }^{290}$ A federal court basically has two options. Option one, which I refer to as "adopting," is to fully adopt state law on the issue. ${ }^{291}$ Under this

\section{Id. $\S 425$.}

286. See id. $\S 14 \mathrm{C}$ ("Neither the board of directors nor an individual director of a business is, as such, an agent of the corporation or of its members.").

287. See id. § 2 ("A master is a principal who employs an agent to perform service in his affairs. ... A servant is an agent employed by a master to perform service in his affairs whose physical conduct in the performance of the service ... is subject to the right to control by the master.").

288. See supra note 101 and accompanying text.

289. See supra note 102 and accompanying text. 103.

290. Stephen M. Bainbridge, Incorporating State Law Fiduciary Duties into the Federal Insider Trading Prohibition, 52 WASH. \& LEE L. REV. 1189, 1208 (1995).

291. See Charles Alan Wright \& Mary Kay Kane, LaW of Federal Courts 421 (6th ed. 2002) (discussing federal courts' options when federal statutes are silent on a particular issue). Burks v. Lasker, 441 U.S. 471 (1979), provides an example of the Supreme Court choosing to adopt. See infra text accompanying notes 297-322 for a discussion of the case. 
approach, federal law will vary depending on which state's laws are applicable. ${ }^{292}$ Option two, which I refer to as "fashioning," is to fashion independent federal doctrine on the issue, drawing on state law by analogy as appropriate. ${ }^{293}$ For the reasons discussed below, I believe federal courts should use a fashioning approach in defining the fiduciary duties owed under section 36(a).

Fashioning appears to be the approach endorsed by the courts in many of the cases discussed above in Part IV.A. For example, the Moses court referenced "general principles governing fiduciaries in the area of self-dealing" and concluded that they are expressed "through the federally imposed standard under section 36, which may vary from state common law." ${ }^{294}$ Likewise, in both Fogel and Tannenbaum the courts stated that section 36 "established a federal standard of fiduciary duty in dealings between a mutual fund and its adviser." ${ }^{295}$ Finally, in Goldstein the court stated that section 36(a) "imposes a federal standard for fiduciary obligations owed to shareholders by directors and other officers of mutual funds. $" 296$

Conversely, the Supreme Court chose an adopting approach in Burks v. Lasker ${ }^{297}$ and Kamen v. Kemper Financial Services, Inc. ${ }^{298}$ Both cases involved issues under the ICA. Moses, Tannenbaum, and Fogel were decided before Burks and Kamen, so their precedential value on the issue can be discounted. Goldstein, however, was decided after Burks and Kamen, but does not discuss either case, putting its precedential value into question. I discuss both Burks and Kamen in detail below.

In Burks, shareholders of an investment company brought a derivative suit against several of the company's directors and the

292. See Theresa A. Gabaldon, State Answers to Federal Questions: The Common Law of Federal Securities Regulation, 20 J. CORP. L. 155, 159 (1995) (discussing situations where federal courts have fully adopted state law on an issue).

293. Wright \& KANE, supra note 291, at 421. See also Bainbridge, supra note 290, at 1208 (discussing the extent to which state law fiduciary duty concepts should be incorporated into federal fiduciary duty requirements). SEC v. W.J. Howey Co., 328 U.S. 293 (1946), provides an example of the Supreme Court choosing to adopt. In this case, the Court established the definition of the term "investment contract" for purposes of the definition of "security" as used in the Securities Act. To do so, the Court drew on state court decisions addressing the definitional issue under state securities regulations to fashion the federal definition. Id. at 298-99.

294. Moses v. Burgin, 445 F.2d 369, 376 (1st Cir. 1971).

295. Fogel v. Chestnutt, 533 F.2d 731, 745 (2d Cir. 1975); Tannenbaum v. Zeller, 552 F.2d 402, 416 (2d Cir. 1971).

296. Goldstein v. Lincoln Nat. Convertible Secs. Fund, Inc., 140 F. Supp. 2d 424, 436 (E.D. Pa. 2001).

297. 441 U.S. 471 (1979).

298. 500 U.S. 90 (1991). 
company's investment adviser. ${ }^{299}$ The suit alleged that the defendants violated duties owed by them under the ICA, the Investment Advisers Act of 1940 (IAA), and common law in connection with an investment by the company in Penn Central Transportation Co. commercial paper. ${ }^{300}$ In response, the company's board of directors decided that the five directors unaffiliated with the investment adviser and not named in the suit would investigate the allegations and determine whether the company should continue the suit or move for dismissal. ${ }^{301}$ The board deemed this appropriate because it considered these five directors to be disinterested in the matter and five directors constituted a quorum under the company's bylaws. ${ }^{302}$ After the five directors concluded that continuing the litigation was not in the best interests of the company or its shareholders, the company moved for dismissal. ${ }^{303}$ The district court held that if the five directors were truly disinterested and independent, their decision to move for dismissal was protected by the businessjudgment rule, and therefore not subject to second guessing by the court. ${ }^{304}$ In a later decision, the district court held that the plaintiffs had failed to prove that the five directors were not disinterested or independent. ${ }^{305}$ Hence, the district court granted summary judgment in favor of the defendants. ${ }^{306}$

In granting summary judgment, the district court rejected the plaintiffs' argument that the "broad regulatory legislation" reflected in the ICA and IAA prevented disinterested directors from moving to dismiss the suit. ${ }^{307}$ The court held that the five directors had the power to move for dismissal, a holding that was in accord with state corporate law. ${ }^{308}$ It appears that the court followed an adopting approach in simply applying state corporate law to the issue. 
On appeal, the Second Circuit reversed. ${ }^{309}$ The circuit court found that permitting disinterested directors to dismiss a derivative suit "would be contrary to the public interests which Congress has sought to protect" through enactment of ICA and IAA. ${ }^{310}$ It therefore held that "disinterested directors of an investment company do not have the power to foreclose the continuation of nonfrivolous litigation brought by shareholders against majority directors for breach of their fiduciary duties." 311 Hence, the court rejected an adopting approach and instead fashioned a federal rule on the issue.

After granting certiorari, ${ }^{312}$ the Supreme Court reversed. ${ }^{313}$ The Court held that "federal courts should apply state law governing the authority of independent directors to discontinue derivative suits to the extent such law is consistent with policies of the ICA and IAA."314 The court reasoned that the issue involved determining the powers of corporate directors. ${ }^{315}$ Therefore, the starting point should be state corporate law because it "is the font of corporate directors' power," 316 whereas "federal law in this area is largely regulatory and prohibitory in nature - it often limits the exercise of directorial power, but only rarely creates it." ${ }^{317}$ Hence, the Court rejected the Second Circuit's reasoning that nothing in ICA or IAA suggested that disinterested directors had the power to terminate derivative suits because the "[t]he ICA does not purport to be the source of authority for managerial power." 318

The Court therefore concluded that " $[\mathrm{t}] \mathrm{he}$ ICA and IAA ... do not require that federal law displace state laws governing the powers of directors unless the state laws permit action prohibited by the Acts, or unless 'their application would be inconsistent with the federal policy underlying the cause of action." "319 The Court then found that allowing independent directors of an investment company to terminate a derivative suit was not inconsistent with the ICA. ${ }^{320}$ The Court based this finding on its conclusion that "the structure and purpose of the ICA

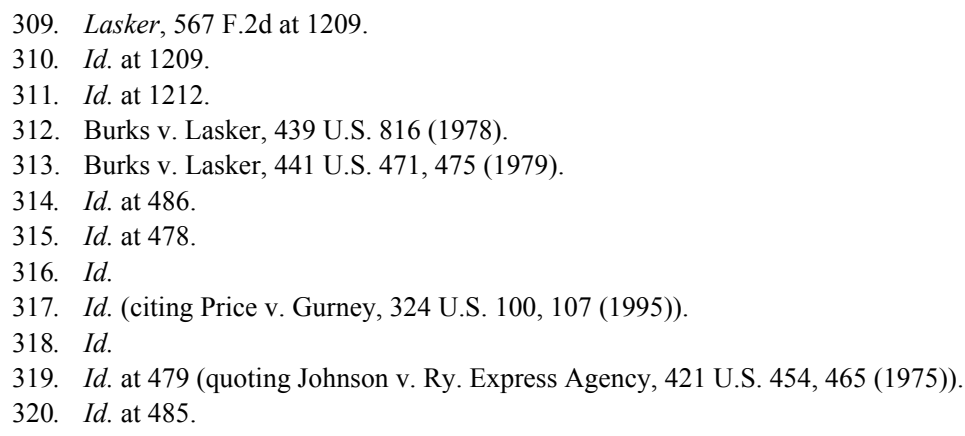


indicate that Congress entrusted to the independent directors of investment companies, exercising the authority granted to them by state law, the primary responsibility for looking after the interests of the funds' shareholders." 321 Thus, there could be situations where an investment company's independent directors could reasonably believe that dismissing a derivative suit was in the best interests of its shareholders. ${ }^{322}$

Twelve years later, the Court reaffirmed and applied the holding of Burks in Kamen v. Kemper Financial Services, Inc. ${ }^{323}$ The case involved a derivative suit on behalf of the money-market fund, Cash Equivalent Fund, Inc., against the fund's investment adviser. ${ }^{324}$ The suit alleged a violation of ICA section 20(a), which prohibits the use of materially misleading statements in connection with a proxy solicitation. ${ }^{325}$ Generally, prior to bringing a derivative suit, a plaintiff must make a demand on the corporation's board of directors to cause the corporation to bring the suit itself. $^{326}$ Many state courts, however, excuse this demand requirement if making it would be futile. ${ }^{327}$ Here, the plaintiff asserted that she did not make a demand on the fund's board of directors because doing so would have been futile. ${ }^{328}$ On appeal, the Seventh Circuit found that the plaintiff's claim was based on federal substantive law and hence federal law governed the demand requirement. ${ }^{329}$ The court then held that there was no futility exception to the demand

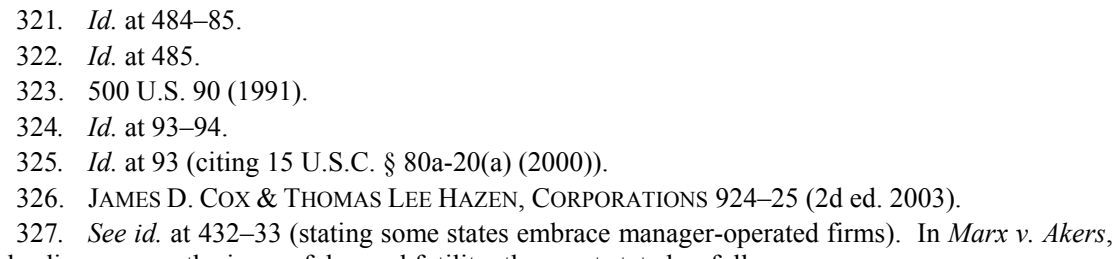
a leading case on the issue of demand futility, the court stated as follows:

(1) Demand is excused because of futility when a complaint alleges with particularity that a majority of the board of directors is interested in the challenged transaction. Director interest may either be self-interest in the transaction at issue, or a loss of independence because a director with no direct interest in a transaction is "controlled" by a selfinterested director. (2) Demand is excused because of futility when a complaint alleges with particularity that the board of directors did not fully inform themselves about the challenged transaction to the extent reasonably appropriate under the circumstances. The "long-standing rule" is that a director "does not exempt himself from liability by failing to do more than passively rubber-stamp the decisions of the active managers." (3) Demand is excused because of futility when a complaint alleges with particularity that the challenged transaction was so egregious on its face that it could not have been the product of sound business judgment of the directors.

666 N.E. 2d 1034, 1040-41 (N.Y. 1996).

328. Kamen v. Kemper Fin. Servs., Inc., 908 F.2d 1338, 1341 (7th Cir. 1990), rev'd, 500 U.S. 90 (1991).

329. Id. at 1342 . 
requirement under federal law and affirmed the lower court's dismissal of the claim for failure to make a demand. ${ }^{330}$

The Supreme Court granted certiorari and addressed the issue of whether federal or state law should define the scope of the demand requirement. ${ }^{331}$ The Court started with the proposition that "a court should endeavor to fill the interstices of federal remedial schemes with uniform federal rules only when the scheme in question evidences a distinct need for nationwide legal standards or when express provisions in analogous statutory schemes embody congressional policy choices readily applicable to the matter at hand." 332 If neither is the case, "federal courts should 'incorporat[e] [state law] as the federal rule of decision,' unless 'application of [the particular] state law [in question] would frustrate specific objectives of the federal programs." 333 The Court then noted that "[t]he presumption that state law should be incorporated into federal common law is particularly strong in areas in which private parties have entered legal relationships with the expectation that their rights and obligations would be governed by statelaw standards," 334 and concluded that "[c]orporation law is one such area." $" 335$

The Court then turned to the question of "whether the demand requirement comes within the purview of Burks's presumption of statelaw incorporation, that is, whether the scope of the demand requirement affects the allocation of governing power within the corporation."336 The Court found that the parameters of when a demand is required and when it is excused determine "who has the power to control corporate litigation," and hence relate "to the allocation of governing powers within the corporation." 337 The Court noted that the "purpose of requiring a precomplaint demand is to protect the directors' prerogative to take over the litigation or to oppose it." 338 Therefore, the Court reversed the court of appeals decision, and reaffirmed Burks v. Lasker:

Where a gap in the federal securities laws must be bridged by a rule that bears on the allocation of governing powers within the corporation,

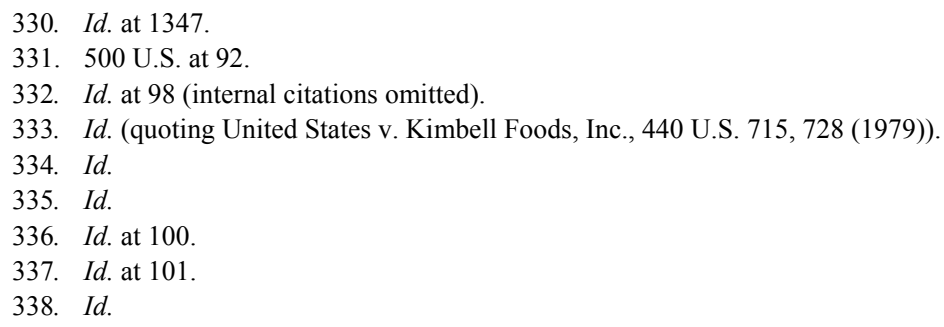


federal courts should incorporate state law into federal common law unless the particular state law in question is inconsistent with the policies underlying the federal statute. ${ }^{339}$

Incorporating state fiduciary duty law into ICA section 36(a) would be inconsistent with the policies underlying the ICA. As the Supreme Court stated in Burks, "Congress' purpose in structuring the [ICA] as it did is clear. It 'was designed to place the unaffiliated directors in the role of 'independent watchdogs,' who would 'furnish an independent check upon the management' of investment companies." 340 In contrast, the role of directors of traditional corporations is not that of watchdogs but to provide broad oversight. ${ }^{341}$ This view is reflected in the Caremark case discussed above $\mathrm{e}^{342}$ - corporate directors have no duty to "ferret out" wrongdoing, but they do have a duty "to attempt in good faith to assure that a corporate information and reporting system, which the board concludes is adequate, exists." 343 In my mind, one role of a watchdog may be to ferret out wrongdoing, but the position certainly involves more than just providing broad oversight. ${ }^{344}$ Hence, investment company independent directors are held to a higher standard than their counterparts at traditional corporations. It would therefore be inconsistent with the policies underlying the ICA to apply state corporate law fiduciary duty rules to directors of investment companies.

Further, investment companies are simply different animals than traditional corporations. As the Court noted in Burks:

[investment companies], with rare exception, are not operated by their own employees. Most funds are formed, sold, and managed by external organizations, [called "investment advisers,"] that are separately owned and operated.... The advisers select the funds' investments and operate their businesses. ...

Since a typical fund is organized by its investment adviser which provides it with almost all management services ..., a mutual fund cannot, as a practical matter sever its relationship with the adviser. Therefore, the forces of arm's-length bargaining do not work in the

339. Id. at 108 .

340. Burks v. Lasker, 441 U.S. 471, 484 (1979) (internal citations omitted) (quoting Tannenbaum v. Zeller, 552 F.2d 402, 406 (2d Cir. 1977)).

341. See supra text accompanying notes 201-05. The Westlaw search I conducted on February 15,2005 , in the All States database did not locate a single case where a court referred to the directors of a traditional corporation as "watchdogs."

342. See supra notes $214-23$ and accompanying text.

343. In re Caremark Int'1, Inc., 698 A.2d 959, 970 (Del. Ch. 1996).

344. Webster's Dictionary defines "watchdog" as "one that guards against loss, waste, theft, or undesirable practices.” WeBSTER's THIRD NEW INTERNATIONAL DiCTIONARY 2581 (1981). 
mutual fund industry in the same manner as they do in other sectors of the American economy. ${ }^{345}$

The unique structure of investment companies has been characterized as "business incest" and as a "corporate anomaly." 346 It just does not make sense to apply only state corporate law fiduciary duty rules designed for a traditional corporation to a "corporate anomaly." State courts simply have had no occasion to tailor fiduciary duties for the unique structure of investment companies. As demonstrated by the recapture cases discussed above, it is sometimes necessary to fashion fiduciary duties to deal with misconduct not specifically addressed in the ICA. ${ }^{347}$

The appropriateness of a fashioning approach is also bolstered by subsection (a)(5) of ICA section 1, Findings and Declaration of Policy, which provides that "the activities of [investment] companies, extending over many States, their use of the instrumentalities of interstate commerce and the wide geographic distribution of their security holders, make difficult, if not impossible, effective State regulation of such companies in the interest of investors." 348 This is because a fashioning approach would create national uniform rules, whereas an adopting approach would result in variation depending on which state's laws applied. A similar argument was specifically rejected by the Court in Burks. ${ }^{349}$ In the context of section 36(a), however, the argument is more compelling. Without national uniform rules, three separate bodies of state law are potentially relevant - corporate law, business trust law, and agency law. Roughly half of all funds are organized as corporations and the other half are organized as business trusts. ${ }^{350}$ If a fund is organized as a corporation, the corporate law of the state of incorporation would dictate the fiduciary duties owed by officers and directors of the fund. If the fund is organized as a business trust, the business trust law of the state of organization would dictate the fiduciary duties owed by the officers and members of the board of trustees of the fund. Finally,

345. Burks, 441 U.S. at 480-81 (quoting S. REP. No. 91-184, at 5 (1969) as repinted in 1910 U.S.C.C.A.N. 4897, 4901).

346. Clarke Randall, Fiduciary Duties of Investment Company Directors and Management Companies under the Investment Company Act of 1940, 31 OKLA. L. REV. 635, 636 (1978).

347. For example, as discussed above, federal courts have developed a duty of disclosure owed by a fund's investment advisers and affiliated directors to the fund's independent directors with respect to the possibility of recapture, payment of legal expenses or simultaneous trading. See supra Part IV.A.

348. 15 U.S.C. $\S 80 a-1(a)(5)(2000)$.

349. Burks, 441 U.S. at 479 n. 6.

350. ROBERTSON, supra note $25, \S 2.02$, at 2-12 n.1. 
because an investment adviser is not an officer, director, or trustee of a fund, state agency law would dictate the fiduciary duties owed by the investment adviser.

As the cases discussed above illustrate, it is not uncommon for a section 36(a) case to involve claims against some or all of the fund's directors and officers and the fund's investment adviser. Hence, if an adopting approach were used, a court could find itself having to apply the corporate or business trust fiduciary duty rules of the state in which the fund is organized, and the agency fiduciary duty rules of the state governing the agency relationship between the adviser and the fund (which very well could be different from the state in which the fund is organized). This means potentially different standards applied to various defendants for the same actions. Further, an adopting approach may impact the application of a fund's raincoat provision. Raincoat provisions do not generally trump federal law. ${ }^{351}$ However, one could certainly argue that they should trump federal laws that simply incorporate state law. These potential complications would be avoided by a fashioning approach.

Following a fashioning approach for section 36(a) can be distinguished from the Court using an adopting approach in Burks and Kamen on two additional grounds. First, in both Burks and Kamen, the Court bolstered its decision to adopt state law for the issue under consideration because "[t]he ICA does not purport to be the source of authority for managerial power; rather, the [ICA] functions primarily to '[impose] controls and restrictions on the internal management of investment companies.",352 In Burks, as discussed above, the Court used this proposition to reject the court of appeals' assertion that disinterested directors did not have the power to dismiss a derivative suit because nothing in the ICA gave them this power. ${ }^{353}$ In Kamen, the Court used this proposition to reject the court of appeals' finding of no demandfutility exception under federal law because the Court viewed such a rule as giving directors greater power with respect to derivative litigation than state law provided them. ${ }^{354}$ Conversely, it seems likely that any fiduciary duty rules fashioned by federal courts under section 36(a) will either be

351. See 2 KNEPPER \& BAILEY, supra note 201, § 16.02, at 16-4 ("[N]o state statute affects in any way any director or officer liability from federal laws; the constitutional preemption doctrine gives precedence to federal law over inconsistent state law.").

352. Burks, 441 U.S. at 478 (quoting United States v. Nat'l Ass'n of Sec. Dealers, 422 U.S. 694, 705 n.13 (1975)). See also Kamen v. Kemper Fin. Servs., Inc., 500 U.S. 90, 107 (1990) (quoting Burks, 441 U.S. at 478).

353. 441 U.S. at 478.

354. 500 U.S. at $107-08$. 
addressing issues not addressed under state fiduciary duty law (for example, the federal duty to disclose under section 36(a) discussed above), or, given the "potential for abuse inherent in the structure of investment companies, "355 be at least as strict as, if not stricter than, analogous state law. Both situations are consistent with the ICA function of restricting internal management of investment companies.

Second, both Burks and Kamen involved interstitial lawmaking or gap-filling. The ICA is silent on whether independent directors of an investment company could dismiss a derivative claim under the ICA. Likewise, the ICA is silent on the scope of the demand requirement in a derivative suit. In fact, the ICA says nothing about derivative suits. Hence, the Court filled these gaps through the incorporation of state law. In contrast, defining the scope of fiduciary duties owed under ICA section 36(a) could fairly be described as statutory interpretation and not as interstitial lawmaking. Federal courts would merely be interpreting the statutory language "breach of fiduciary duty." It is well accepted that federal courts are freer to develop federal rules in the context of statutory interpretation as opposed to statutory gap-filling. ${ }^{356}$

Finally, using a fashioning approach to section 36(a), which would require federal courts to develop fiduciary duty law, is distinguishable from Santa Fe Industries, Inc. v. Green, ${ }^{357}$ a case where the Court rejected creating a federal law of fiduciary duty for purposes of section 10(b) of the Securities Exchange Act of 1934 (Exchange Act) and Rule 10b-5 thereunder. ${ }^{358}$ First, in Santa Fe, the Court was not interpreting specific language in a federal statute. Instead, it was addressing how a gap in judicially developed law under section 10(b) of the Exchange Act and Rule 10b-5 thereunder should be filled. ${ }^{359}$ Additionally, the Court was concerned that federalizing the standards of fiduciary duty would result in "overlap and quite possibly interfere[nce] with state corporate law." congressional intent, the Court should be reluctant to federalize the substantial portion of the law of corporations that deals with transactions in securities, particularly where established state policies of corporate

355. Burks, 441 U.S. at 480.

356. Gabaldon, supra note 292, at 172-73.

357. 430 U.S. 462 (1977).

358. Id. at $478-79$.

359. The Court has characterized the jurisprudence under section 10(b) and Rule 10b-5 of the Exchange Act as "a judicial oak which has grown from little more than a legislative acorn." Blue Chip Stamps v. Manor Drug Stores, 421 U.S. 723, 737 (1975).

360. Santa Fe, 430 U.S. at 479. 
regulation would be overridden." 361 Applying a fashioning approach to section 36(a) would result in some overlap but would neither interfere with nor federalize a substantial portion of corporate law. On the contrary, it would only federalize fiduciary duty law with respect to a small, finite set of actors-directors, officers, investment advisers, and underwriters of investment companies, an area in which state courts have had no occasion to delve. Finally, the Court did indicate in Santa Fe that it may be appropriate to federalize fiduciary duty standards in a context other than section 10(b) and Rule 10b-5. ${ }^{362}$ ICA section 36(a) is just such a context.

\section{V. "INVOLVING PERSONAL MisCONDUCT"}

As noted above, ICA section 36(a) provides a cause of action for "a breach of fiduciary duty involving personal misconduct." This section explores the issue of what sort of breach involves "personal misconduct."

\section{A. Legislative History and Case Law}

The ICA is silent on the meaning of the phrase "involving personal misconduct," but the legislative history of the 1970 amendment to section 36 that established this standard does provide some limited guidance. Specifically, the Senate Committee report on the underlying bill states that the standard is "not intend[ed] to limit the [SEC] under this section to situations where an actual intent to violate the law can be shown or to acts of affirmative misconduct. In appropriate cases, nonfeasance of duty or abdication of responsibility would constitute a breach of fiduciary duty involving personal misconduct." ${ }^{363}$

Initially, most, if not all, reported cases where a defendant was found liable under ICA section 36(a) involved fraud or self-interested behavior. ${ }^{364}$ This led defendants in section 36(a) cases to argue that the

361. Id.

362. See id. at $479-80$ ("There may well be a need for uniform federal fiduciary standards to govern mergers such as that challenged in this complaint. But those standards should not be supplied by judicial extension of $\S 10(\mathrm{~b})$ and Rule 10b-5 to "cover the corporate universe." (quoting William L. Cary, Federalism and Corpoate Law: Reflections Upon Delaware, 83 YALE L.J. 663, $700(1974)))$.

363. S. REP. NO. 91-184, at 36 (1969).

364. See, e.g., SEC v. Commonwealth Chem. Sec., Inc., 410 F. Supp. 1002, 1018 (S.D.N.Y. 1976), aff'd in part, modified in part, 574 F.2d 90 (2d Cir. 1978); SEC v. Vintage Group, Inc., Litigation Release No. 14319, S7 S.E.C. Docket 1988 (Nov. 2, 1994), available at 1994 WL 615222; SEC v. Strategic Mgmt., Inc., Litigation Release No. 13701, S4 S.E.C. Docket 1219 (July 9, 
"involving personal misconduct" standard required a plaintiff to allege fraud or self-dealing by the defendant. ${ }^{365}$

Several courts, however, disagreed with this interpretation. For example, in Seidel v. Lee, ${ }^{366}$ the plaintiff, an investor in the ML-Lee Acquisition Fund, L.P., brought a class action lawsuit against the managing partners of the fund and the fund's underwriter, among others. ${ }^{367}$ The plaintiff alleged, among other things, that the defendants violated section 36(a) of the ICA in connection with recommending an alleged unlawful transaction to the fund. ${ }^{368}$

Defendants moved to dismiss the claim arguing that "the personal misconduct" standard of section 36(a) "only permits liability in cases involving self-dealing, conflict of interest or some personal gain to the defendant,"369 and the complaint did not allege that the defendants engaged in this type of misconduct. ${ }^{370}$ While the court noted that many section 36(a) cases involved one of these three types of misconduct, it refused to limit the standard to the three types. ${ }^{371}$ In support, the court noted that in Burks the Supreme Court established that independent fund directors serve as watchdogs "whose primary function is to 'supply an independent check on management and to provide a means for the representation of shareholder interests in investment company affairs." "372 Hence, the court concluded that a direct breach of fiduciary duties "is a form of personal misconduct.",373

Likewise, in In re Nuveen Fund Litigation, ${ }^{374}$ plaintiffs brought a derivative suit on behalf of two Nuveen mutual funds against the funds' adviser and directors. ${ }^{375}$ The plaintiffs alleged, among other things, that the defendants violated ICA section 36(a) by approving rights offerings

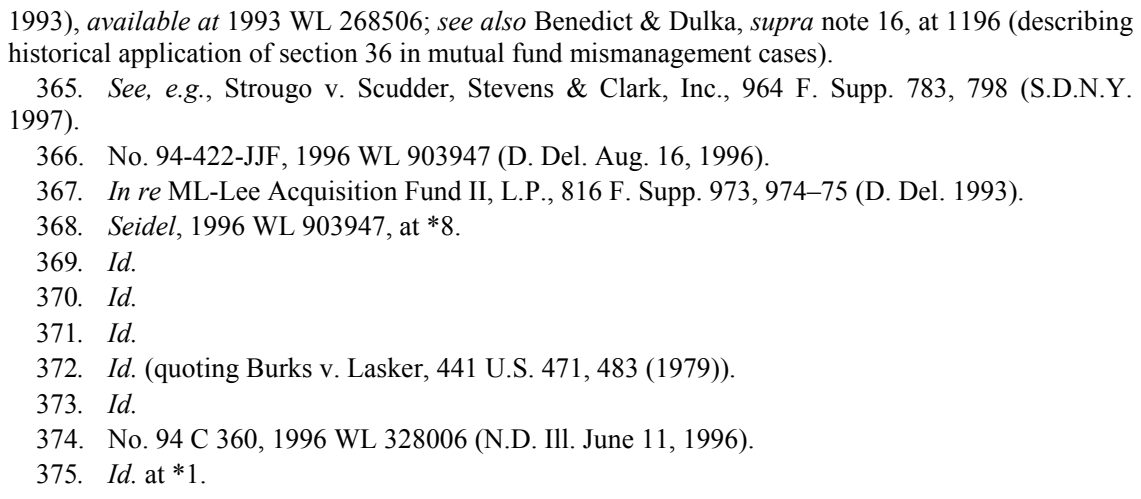


by the funds for the advisers' benefit rather than for the benefit of the funds' shareholders. ${ }^{376}$

As in Seidel, defendants argued that "the duty under § 36(a) cannot reach all misconduct governed under a traditional fiduciary duty.",377 Here, however, the defendants pointed to a principal of statutory construction - "statutory language should not be treated as surplusage",378 — and argued that interpreting section 36(a) to encompass any breach of fiduciary duty would treat the statutory language "involving personal misconduct" as surplusage. ${ }^{379}$ In addition, the defendants noted that the Senate Report from the 1970 amendments to section 36 states that it "is not intended to provide a basis for the Commission to undertake a general revision of the practices or structures of the investment company industry," 380 and argued that "this language indicates that Congress did not intend that $\S 36$ (a) reach all breaches of due care." 381

The court found that " $\$ 36$ (a) contemplates allegations of a director's gross neglect of his responsibility to supervise and inform himself of the investment adviser's management of the fund." ${ }^{382}$ The court based this finding on the legislative history of the 1970 amendment mentioned above with respect to "nonfeasance of duty" or "abdication of responsibility" potentially constituting "a breach of fiduciary duty involving personal misconduct." 383 It also mentioned the independent watchdog role of directors established in Burks. ${ }^{384}$ Finally, the court cited a House of Representatives committee report with respect to the 1980 amendments to the ICA, which similarly stated that section 36(a) "extends to personal misconduct evidenced by misfeasance or nonfeasance in carrying out legal responsibilities as well as self-dealing and other examples of unjust enrichment." 385

The court reached a similar conclusion in Strougo v. Scudder, Stevens \& Clark, Inc. ${ }^{386}$ In this case, the plaintiff, a shareholder of The

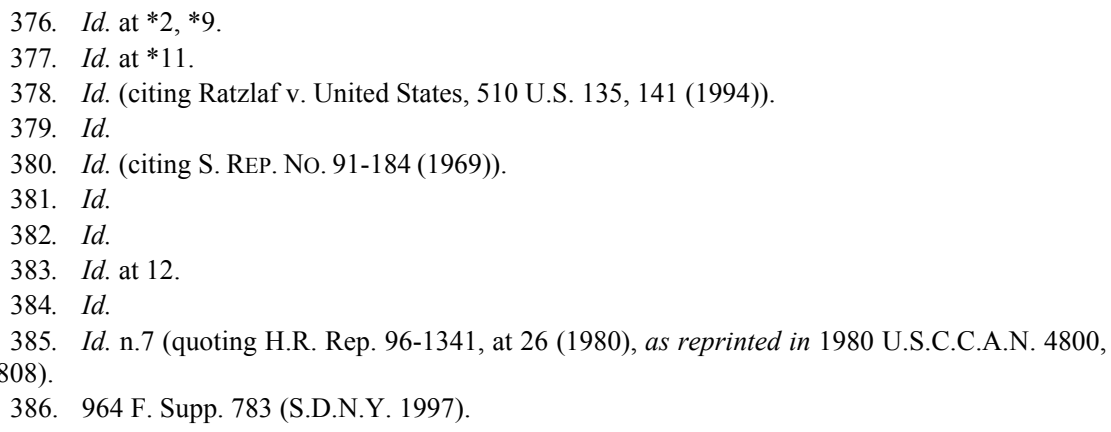


Brazil Fund, Inc., a closed-end fund, brought a class action lawsuit against the fund's investment adviser and directors. ${ }^{387}$ The plaintiff alleged, among other things, that the defendants breached section 36(a) in connection with their involvement in the development and implementation of a rights offering by the fund. ${ }^{388}$ In particular, the plaintiff claimed that the defendants launched the rights offering to increase the fund's capital, which would thereby increase the adviser's compensation, ${ }^{389}$ and that this constituted a breach of the fiduciary duties of loyalty and due care. ${ }^{390}$

Defendants moved to dismiss the section 36(a) claim on grounds that the plaintiff "failed to allege 'personal misconduct' within the meaning of the statute." 391 Specifically, the defendants argued that the phrase "involving personal misconduct" required the plaintiff to "allege more than a 'mere' beach of fiduciary duty." 392 They supported this interpretation by noting that "most cases imposing liability under section 36(a) have involved allegations of fraud, self-dealing, or some likelihood of direct personal financial advantage to be derived from the transactions in question." ${ }^{393}$ They then pointed out that as discussed above, prior to 1970 , the analogous standard was "gross misconduct or abuse of trust." 394 When the Senate was considering a different standard, the SEC had proposed to lower the standard to a simple "breach of fiduciary duty." 395 The Senate, however, rejected this standard, noting that it would allow for section 36 claims "based on "nothing more than a difference of opinion about the most debatable management problems.",396 The defendants therefore argued that this rejection indicated that the "personal misconduct" standard involved more than a mere breach of a fiduciary duty, i.e., it required fraud or self dealing. ${ }^{397}$

The court rejected these arguments and therefore denied the defendants' motion to dismiss the section 36(a) claim. ${ }^{398}$ The court based its decision on several grounds. First, the court reasoned that:

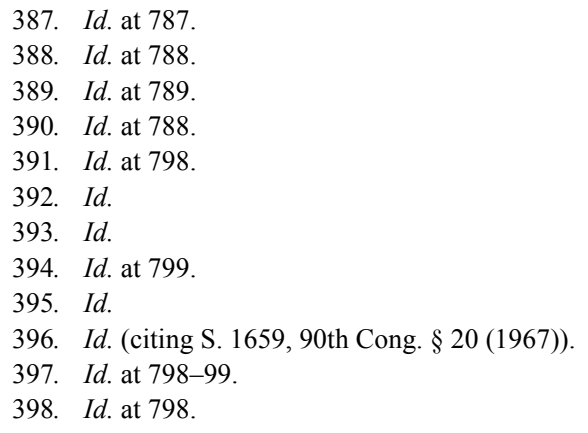


Section 36 . . was designed as a "reservoir of fiduciary obligations" to prevent more "subtle abuses ... not otherwise specifically dealt with in the Act." Such abuses include a director's "lack of independence resulting in the subordination of the stockholders' interest to that of management." [Plaintiff] has alleged that precisely such a lack of independence led the directors to approve the Rights Offering to benefit [the corporation], without regard to the consequences for the Fund. ${ }^{399}$

Second, the court examined the legislative history of the 1970 amendments and concluded "[it] does not indicate an intention to require allegations of fraud or self-dealing., ${ }^{, 400}$ Like the court in Nuveen, it based this conclusion on the legislative history mentioned above with respect to "nonfeasance of duty" or "abdication of responsibility" potentially constituting "a breach of fiduciary duty involving personal misconduct." T01 Third, the court stated that "[a]lthough, as defendants note, most of the cases finding section 36(a) liability involved fraud or self-dealing, defendants do not cite any case law squarely rejecting a claim under section 36(a) for failure to allege fraud or self-dealing." 402

The court in Young v. Nationwide Life Insurance Company ${ }^{403}$ followed reasoning similar to the above cases in refusing to limit the phrase "involving personal misconduct" to misconduct involving "selfdealing or personal impropriety." 404 Like the Nuveen and Strougo courts, it cited the "nonfeasance of duty" and "abdication of responsibility" language in the legislative history of the 1970 amendment to section $36{ }^{405}$ Like the Seidel and Nuveen courts, it also recited the role of independent directors established by Burks. ${ }^{406}$ Finally, like the Strougo court, it noted that "[d]efendants have failed to cite any authority rejecting a [section 36(a)] claim where self-dealing or conflicts of interest are not involved.'

The courts in the above cases make clear that in their view the section 36(a) "involving personal misconduct" standard is not limited to fraud, self-dealing, conflict of interest, or the like. They do not make clear, however, whether any breach of fiduciary duty "involves personal misconduct." Seidel may suggest that the answer is yes because, as

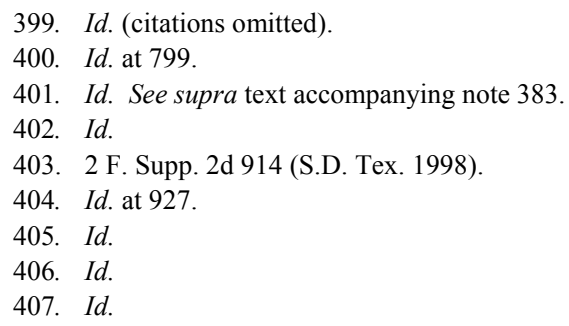


noted above, Seidel states that a direct breach of fiduciary duties "is a form of personal misconduct." ${ }^{408}$ Seidel does not, however, define "direct breach," so it is unclear whether it means "any breach" or something less than "any breach."

In the recent case of SEC v. PIMCO Advisors Fund Management $L L C^{409}$ the court was clear on whether any breach of fiduciary duty "involves personal misconduct." The case involved an enforcement action by the SEC against the investment advisers and related entities of certain PIMCO mutual funds and Stephen Treadway and Kenneth Corba, each of whom served in various executive capacities for the advisers and related entities. ${ }^{410}$ The enforcement action arose out of an alleged arrangement orchestrated by Treadway and Corba on behalf of various PIMCO entities that allowed Canary Capital $^{411}$ to engage in market timing $^{412}$ in certain PIMCO funds. ${ }^{413}$

The SEC settled with the PIMCO entities but continued to pursue claims against Treadway and Corba. ${ }^{414}$ In particular, the SEC alleged that Treadway and Corba violated ICA section 36(a) through their involvement in the Canary arrangement. ${ }^{415}$ In denying Treadway's motion to dismiss the section 36(a) claim, the court held that "to demonstrate a violation of section 36(a), the SEC does not have to allege fraud or self-dealing; instead, it must demonstrate an accepted breach of fiduciary duty via affirmative acts or, in [sic] 'in appropriate cases, nonfeasance of duty or abdication of responsibility.",416 The court did not, however, provide much support for this broad interpretation of "involving personal misconduct" other than quoting from Strougo. ${ }^{417}$

In contrast to PIMCO is the recent case of Prescott v. Allstate Life Insurance Co ${ }^{418}$ In Prescott, the plaintiffs entered into annuity contracts with the defendant that allowed the plaintiffs to transfer funds "quickly and freely" among various investments, including mutual funds. ${ }^{419}$

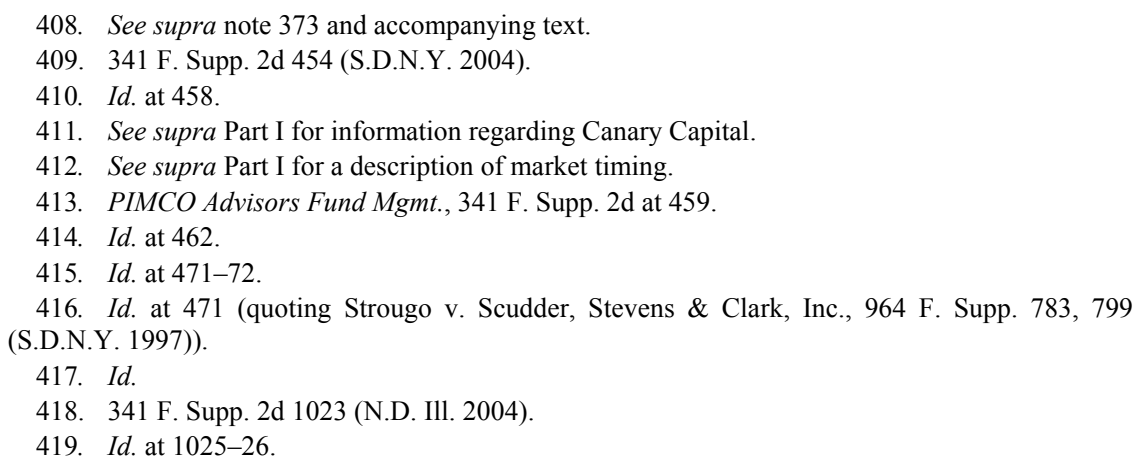


Notwithstanding these contracts, the defendant later disallowed the plaintiffs' requests to transfer money between certain funds and to withdraw money from certain funds. ${ }^{420}$ Hence, the plaintiffs brought suit claiming, among other things, that in disallowing these requests, the defendant violated ICA section $36(\mathrm{a})$. $^{421}$

The defendant moved to dismiss the section 36(a) claim asserting that the plaintiff had "failed to plead personal misconduct." ${ }^{\text {"22 }}$ The court granted the motion reasoning that

[section] 36(a) does not provide redress for a general breach of fiduciary duty. Rather, a cognizable claim must contain allegations of a breach "involving personal misconduct;" to hold otherwise would render these modifying words in the statute superfluous. While other courts have adopted more liberal standards for section 36(a) claims, we find that "personal misconduct" refers to "misconduct that involves self-dealing by investment company or other insiders.",423

In further support of this interpretation of section 36(a), the court noted that "Congress adopted the ICA primarily to address the unique problems of investment adviser self-dealing in the investment fund industry." ${ }^{424}$ Hence, presumably section 36(a) should be interpreted to require self-dealing in light of this primary purpose.

\section{B. Recommended Interpretation}

As the above discussion demonstrates, courts disagree as to the appropriate interpretation of the "involving personal misconduct" standard of ICA section 36(a). For the reasons discussed below, the standard should be interpreted to reflect the substance of the businessjudgment rule - an enumerated party under section 36(a) is not liable for what turns out to be a bad business decision as long as the party made the decision "on an informed basis, in good faith and in the honest belief that the action taken was in the best interests of the company." out by the Nuveen, Strougo, and Young courts, interpreting the phrase to

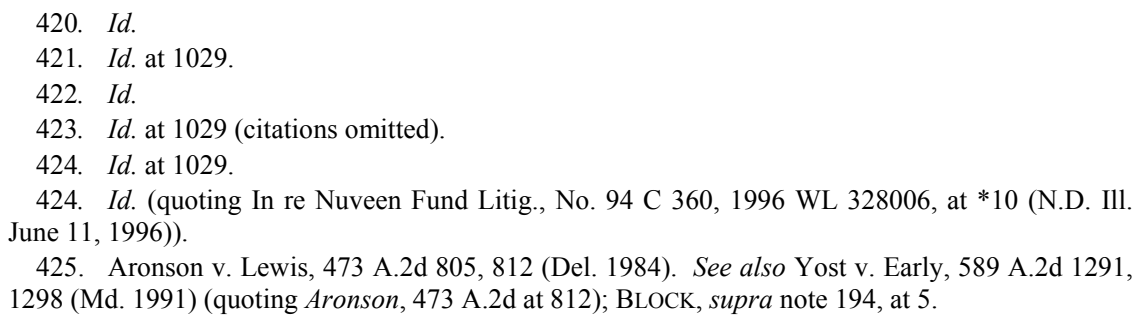


go beyond self dealing and personal impropriety is consistent with the legislative history of section 36(a). Further, as pointed out by the Seidel, Nuveen, and Young courts, such an interpretation is also consistent with the teaching of Burks that Congress intended unaffiliated directors of investment companies to serve as independent watchdogs.

My proposed interpretation is supported by another portion of the legislative history of the 1970 amendments to section 36. Specifically, as discussed above, when the Senate was considering changing the pre1970 "gross misconduct or abuse of trust" standard, the SEC proposed going with a simple "breach of fiduciary duty" standard. ${ }^{426}$ The Senate, however, rejected the SEC's proposed standard, reasoning that it would allow for section 36(a) claims "based on "nothing more than a difference of opinion about the most debatable management problems.",427 This suggests that the "involving personal misconduct" standard was included to foreclose section 36(a) liability for nothing more than a bad business decision, just as the business-judgment rule forecloses courts from second guessing a bad business decision unless the decision maker was not adequately informed, acted in bad faith, or did not believe the decision was in the best interest of the company. Hence, I assert that the phrase "involving misconduct" was not chosen to limit liability to misconduct involving self-dealing or fraud but to federalize the substance of the business-judgment rule for purposes of section 36(a).

My interpretation of the "involving personal misconduct" standard also makes sense in light of the soon-to-be effective requirement that seventy-five percent of a fund's board be comprised of independent directors. ${ }^{428}$ This new requirement will likely result in a need for additional people to serve as independent fund directors - people who will take on the role of independent watchdogs and "bring to the boardroom a "high degree of rigor and skeptical objectivity to the evaluation of management and its plans and proposals.",429 Considering the current climate of ongoing litigation against fund boards, it may be difficult to attract and retain qualified people to serve as independent directors. At the same time, in view of the recent improprieties at various funds and the continued reliance on independent directors to protect the interests of fund shareholders, ${ }^{430}$ the watchdogs must have some degree of accountability. My interpretation strikes the appropriate

\footnotetext{
426. Strougo v. Scudder, Stevens \& Clark, Inc., 964 F. Supp. 783, 799 (S.D.N.Y. 1997).

427. Id. (citing S. 1659, 90th Cong., § 20 (1967)).

428. See supra text accompanying note 87 .

429. Investment Company Governance Release, supra note 15, at*3.

430. See id.
} 
balance between attracting competent individuals to serve as independent fund directors and holding the watchdogs accountable. As noted above, one of the rationales behind the business-judgment rule is to "encourage[s] competent individuals to become directors who otherwise might decline for fear of personal liability."

My interpretation would also extend a type of business-judgment rule protection from section 36(a) liability to investment advisers. As discussed above, an investment adviser is an agent of the fund it advises. Hence, it owes various fiduciary duties to the fund under state agency law. However, there is no equivalent to the business-judgment rule under state agency law. In the context of this particular agency relationship, something like business-judgment rule protection is warranted. The primary job of a fund's investment adviser is to "manage the fund's assets in accordance with the fund's investment objectives." 432 This requires the investment adviser to make daily business decisions with respect to what securities the fund should buy, sell, and hold. Given the nature of investing, many of these decisions will turn out to be bad decisions, e.g., the adviser might decide to buy a stock that later decreases in value or to sell a stock that later increases in value. Certainly, an investment adviser should not be liable under section 36(a) for a bad investment decision that was made with adequate information, in good faith, and in the honest belief it was in the best interest of the fund. This conclusion is strongly supported by the rationale behind the business-judgment rule. ${ }^{43}$ Specifically, as stated earlier, because "potential profit often corresponds to potential risk, it is very much in the interest of shareholders that the law not create incentives for overly cautious corporate decisions." 434 This is particularly true with respect to investment advisers. Managing a fund's portfolio is all about taking calculated risks, and the law should not discourage investment advisers from taking these risks. In fact, the ICA recognizes the risk-taking nature of managing a portfolio through the requirement to describe these risks in the fund prospectus furnished to investors. ${ }^{435}$

431. Air Line Pilots Ass'n v. UAL Corp., 717 F. Supp. 575, 582 (N.D. Ill. 1989). See also BLOCK, supra note 194, at 12.

432. MUTUAL FUND FACT BOOK, supra note 19 , at 8.

433. See supra text accompanying notes $232-45$.

434. See supra note 234 and accompanying text.

435. See SEC Form N-1A, Item 4.c., available at http://www.sec.gov/about/forms/formn-la.pdf ("Disclose the principal risks of investing in the Fund, including the risks which the Fund's particular portfolio as a whole is expected to be subject and the circumstances reasonably likely to affect adversely the Fund's net asset value, yield, or total return."). 
Finally, the "involving personal misconduct" standard should be interpreted to be met even by non-action of the enumerated parties. This point is clear from the legislative history of section 36(a). As noted above, the relevant Senate Report states that the standard is "not intend[ed] to limit ... section [36(a)] to situations where an actual intent to violate the law can be shown or to acts of affirmative misconduct. In appropriate cases, nonfeasance of duty or abdication of responsibility would constitute a breach of fiduciary duty involving personal misconduct." ${ }^{236}$ This language was cited with approval by the courts in Nuveen, Strougo, Young, and PIMCO. ${ }^{437}$ Additionally, a House committee report about the 1980 amendments to the ICA similarly stated that section 36(a) "extends to personal misconduct evidenced by misfeasance or nonfeasance in carrying out legal responsibilities." 438

Consistent with state law, protection like that provided by the business-judgment rule should not be afforded to nonfeasance of duty unless the nonfeasance involved a conscious decision not to act, and this decision was made on an informed basis, in good faith, and in the honest belief that not acting was in the best interest of the investment company. ${ }^{439}$ Again, the business-judgment rule only protects a business judgment. If no judgment is made, the business-judgment rule is inapplicable, and the same analysis should apply to section 36(a) ${ }^{440}$

\section{CONCLUSION}

In the wake of the mutual fund scandal, many plaintiffs have sought to tap the section 36(a) "reservoir of fiduciary obligations" in an effort to hold accountable fund officers, directors, and investment advisers. The interpretation of the section 36(a) phrase "breach of fiduciary duty involving personal misconduct," however, remains unsettled. To aid in settling the issue, this Article has proposed that federal courts fashion federal law as to what fiduciary duties are owed under section 36(a), drawing on analogous state law as appropriate. As discussed above, this approach is consistent with the holdings in Burks $^{441}$ and Kamen. ${ }^{442}$ More

\footnotetext{
436. Senate Report, supra note 101, at 36 .

437. See Young v. Nationwide Ins. Co., 2 F. Supp. 2d 454, 471 (S.D.N.Y. 2004); SEC v. PIMCO Advisors Fund Mgmt., 341 F. Supp. 2d 454, 471 (S.D.N.Y. 2004); Strougo v. Scudder, Stevens \& Clark, Inc., 964 F. Supp. 783, 798 (S.D.N.Y. 1997); In re Nuveen, No. 94 C 360, 1996 WL 328006 , at *10 (N.D. Ill. June 11, 1996).

438. H.R. REP. NO. 96-1341, at 26 (1980), as reprinted in 1980 U.S.C.C.A.N. 4800, 4808.

439. See supra notes $243-45$ and accompanying text.

440. See BLOCK, supra note 194, at 60.

441. Burks v. Lasker, 441 U.S. 471 (1979).
} 
importantly, this approach allows federal courts to tailor fiduciary duty rules for the unique investment company structure as opposed to simply applying state fiduciary duty rules developed for traditional corporations.

This Article has also asserted that the "involving personal misconduct" standard of section 36(a) should be interpreted to encompass more than just self-dealing and personal impropriety. Specifically, the standard should encompass any decision that was not made on an informed basis, in good faith, and in the honest belief that the action taken was in the best interest of the company. This interpretation strikes the appropriate balance between attracting competent individuals to serve as independent fund directors and holding the watchdogs accountable. This interpretation would also extend business-judgmentrule-type protection to investment advisers, a result warranted by the risk-taking nature of portfolio management.

442. Kamen v. Kemper Fin. Servs., Inc., 500 U.S. 90 (1991). 